Published in final edited form as:

Free Radic Res. 2010 May ; 44(5): . doi:10.3109/10715761003667554.

\title{
Reactive oxygen species in cancer
}

\author{
Geou-Yarh Liou and Peter Storz \\ Department of Cancer Biology, Mayo Clinic, 4500 San Pablo Road, Jacksonville FL, 32224, USA
}

\begin{abstract}
Elevated rates of reactive oxygen species (ROS) have been detected in almost all cancers, where they promote many aspects of tumor development and progression. However, tumor cells also express increased levels of antioxidant proteins to detoxify from ROS, suggesting that a delicate balance of intracellular ROS levels is required for cancer cell function. Further, the radical generated, the location of its generation, as well as the local concentration is important for the cellular functions of ROS in cancer. A challenge for novel therapeutic strategies will be the fine tuning of intracellular ROS signaling to effectively deprive cells from ROS-induced tumor promoting events, towards tipping the balance to ROS-induced apoptotic signaling. Alternatively, therapeutic antioxidants may prevent early events in tumor development, where ROS are important. However, to effectively target cancer cells specific ROS-sensing signaling pathways that mediate the diverse stress-regulated cellular functions need to be identified. This review discusses the generation of ROS within tumor cells, their detoxification, their cellular effects, as well as the major signaling cascades they utilize, but also provides an outlook on their modulation in therapeutics.
\end{abstract}

\section{Keywords}

Oxidative stress; reactive oxygen species; cancer; signal transduction

\section{Reactive Oxygen Species}

Reactive oxygen species are radicals, ions or molecules that have a single unpaired electron in their outermost shell of electrons. Due to this character, ROS are highly reactive. ROS can be categorized into two groups: free oxygen radicals and non-radical ROS. Free oxygen radicals include superoxide $\left(\mathrm{O}_{2}{ }^{--}\right)$, hydroxyl radical $\left({ }^{\circ} \mathrm{OH}\right)$, nitric oxide $\left(\mathrm{NO}^{\circ}\right)$, organic radicals $\left(\mathrm{R}^{*}\right)$, peroxyl radicals $\left(\mathrm{ROO}^{\circ}\right)$, alkoxyl radicals $\left(\mathrm{RO}^{*}\right)$, thiyl radicals $\left(\mathrm{RS}^{*}\right)$, sulfonyl radicals (ROS*), thiyl peroxyl radicals ( $\mathrm{RSOO}^{*}$ ), and disulfides (RSSR). Non-radical ROS include hydrogen peroxide $\left(\mathrm{H}_{2} \mathrm{O}_{2}\right)$, singlet oxygen $\left({ }^{1} \mathrm{O}_{2}\right)$, ozone/trioxygen $\left(\mathrm{O}_{3}\right)$, organic hydroperoxides $(\mathrm{ROOH})$, hypochloride $(\mathrm{HOCl})$, peroxynitrite $\left(\mathrm{ONO}^{-}\right)$, nitrosoperoxycarbonate anion $\left(\mathrm{O}=\mathrm{NOOCO}_{2}^{-}\right)$, nitrocarbonate anion $\left(\mathrm{O}_{2} \mathrm{NOCO}_{2}^{-}\right)$, dinitrogen dioxide $\left(\mathrm{N}_{2} \mathrm{O}_{2}\right)$, nitronium $\left(\mathrm{NO}_{2}{ }^{+}\right)$, and highly reactive lipid-or carbohydratederived carbonyl compounds. Among them, superoxide, hydrogen peroxide and hydroxyl radicals are the mostwell studied ROS in cancer.

\footnotetext{
*Correspondence to: Peter Storz, Department of Cancer Biology, Mayo Clinic, Griffin Rm 306, 4500 San Pablo Road, Jacksonville FL, 32224, USA. Phone: 904 953-6909, Fax: 904 953-0277, storz.peter@ mayo.edu.

Declaration of interest:

The authors report no conflicts of interest. The authors alone are responsible for the content and writing of the review.
} 


\section{Cellular sources for ROS}

In cancer cells high levels of reactive oxygen species can result from increased metabolic activity, mitochondrial dysfunction, peroxisome activity, increased cellular receptor signaling, oncogene activity, increased activity of oxidases, cyclooxygenases, lipoxigenases and thymidine phosphorylase, or through crosstalk with infiltrating immune cells [1-3].

In mitochondria, ROS are produced as an inevitable byproduct of oxidative phosphorylation (Figure 1). The electron transport chain encompasses complexes I-IV and ATP synthase on the mitochondrial inner membrane. Superoxide is generated at complexes I and III and released into the intermembrane space (approx. $80 \%$ of the generated superoxide) or the mitochondrial matrix (approx. 20\%) [4]. The mitochondrial permeability transition pore (MPTP) in the outer membrane of the mitochondrion allows the leakage of superoxide into the cytoplasm ([5], and [6] for a more detailed description of mitochondrial ROS generation). Superoxide is dismutated to $\mathrm{H}_{2} \mathrm{O}_{2}$, either in the mitochondrial matrix (by $\mathrm{MnSOD}$ ) or in the cytosol (by $\mathrm{Cu} / \mathrm{ZnSOD}$ ). $\mathrm{H}_{2} \mathrm{O}_{2}$ is a bona fide second messenger that is highly diffusible. Recent data suggest that hydrogen peroxide may cross cellular membranes through specific members of the aquaporin family [7]. For example, aquaporin- 8 was detected in the inner mitochondrial membrane and suggested to function as a channel for water and potentially $\mathrm{H}_{2} \mathrm{O}_{2}$ [8]. In addition to the mitochondria, peroxisomes are other major sites of cellular ROS generation [9]. In these respiratory organelles, superoxide and $\mathrm{H}_{2} \mathrm{O}_{2}$ are generated through xanthine oxidase in the peroxisomal matrix and the peroxisomal membranes $([10,11]$, see [12]for a detailed review on ROS in peroxisomes).

Growth factors and cytokines stimulate the production of ROS to exert their diverse biological effects in cancer [13-16]. For example, an elevation of hydrogen peroxide and nitrite oxide levels was detected in tumor cells in response to interferon $\gamma$ (IFN $\gamma)$ and TNFa $[17,18]$. Further, platelet-derived growth factor (PDGF), epidermal growth factor (EGF), insulin, transforming growth factor $\beta$ (TGF $\beta$ ), interleukin-1 (IL-1), tumor necrosis factor a (TNFa), angiotensin and lysophosphatidic acid all induce the formation of superoxide [13, 16, 19-23]. Activation of the small RhoGTPase K-ras downstream of growth factors or its oncogenic mutation has been tightly associated with increased generation of superoxide and the incidence of various cancers [24-26]. Dependent on the cellular system, growth factors and mutant K-ras elevate intracellular superoxide levels through NADPH oxidase or mitochondria [1]. NADPH oxidase can also be activated via the small GTPase Rac-1 [27]. Rac-1-mediated generation of superoxide is induced by cell surface receptors including cMet [28]. Active Rac-1 further was implicated to induce5-Lipoxygenase (5-LOX)-mediated generation of $\mathrm{H}_{2} \mathrm{O}_{2}[29]$.

Many cancers arise from sites of chronic irritation, infection, or inflammation. Recent data have expanded the concept that inflammation is a critical component of tumor progression [30-32]. Macrophages induce the generation of ROS within tumor cells through secretion of various stimuli, such as TNFa [1]. Production of ROS by neutrophils and macrophages as a mechanism to kill tumor cells is well established. In these cells, a rapid burst of superoxide formation primarily mediated by NAPDH oxidase leads to subsequent production of hydrogen peroxide [33, 34]. Furthermore, during inflammation processes, activated macrophages also generate nitric oxide which reacts with superoxide to produce peroxinitrite radicals that are similar in their activity to hydroxyl radicals and contribute to tumor cell apoptosis [35]. 


\section{Cellular detoxification from ROS}

Under normal physiological conditions, the intracellular levels of ROS are steadily maintained to prevent cells from damage. Detoxification from ROS is facilitated by nonenzymatic molecules (i.e. glutathione, flavenoids and vitamins A, C and E) or through antioxidant enzymes which specifically scavenge different kinds of ROS (Figure 1).

Superoxide dismutases (SODs) are metalloenzymes which catalyze the dismutation of superoxide anion to oxygen and hydrogen peroxide. They ubiquitously exist in eukaryotes and prokaryotes. Superoxide dismutases utilize metal ions such as copper $\left(\mathrm{Cu}^{2+}\right)$, zinc $\left(\mathrm{Zn}^{2+}\right)$, manganese $\left(\mathrm{Mn}^{2+}\right)$ or iron $\left(\mathrm{Fe}^{2+}\right)$ as cofactors. The different SOD enzymes are located in different compartments of the cell and are highly specific in regulating linked biological processes[36].

Catalase facilitates the decomposition of hydrogen peroxide to water and oxygen. The major localization of catalase in most eukaryotes is in the cytosol and peroxisomes [37-39]. Peroxiredoxins are thioredoxin peroxidases that catalyze the reduction of hydrogen peroxide, organic hydroperoxides and peroxynitrite [40-42]. They are divided into three classes: typical 2-cysteine peroxiredoxins (PrxI-IV), atypical 2-cysteine peroxiredoxins $(\operatorname{PrxV})$, and 1-cysteine peroxiredoxins (PrxVI). Interestingly, PrxI knockout mice show increased levels of oxidative stress and die prematurely of cancer [43]. The thioredoxin system consists of thioredoxin and thioredoxin reductase. The catalytic site of thioredoxin contains two neighboring cysteines which are cycled between an active (reduced) dithiol form and an oxidized disulfide form [44]. In its active state, thioredoxin scavenges reactive oxygen species and keeps proteins in their reduced state [45]. Thioredoxin is regenerated by thioredoxin reductases which utilize NADPH as an electron donor [46].

The glutathione system includes glutathione (GSH), glutathione reductase, glutathione peroxidases (GPX) and glutathione S-transferases (GST). Glutathione protects cells from oxidative stress by reducing disulfide bonds of cytoplasmic proteins to cysteines. During this process, glutathione is oxidized to glutathione disulfide (GSSG). Glutathione peroxidases (GPX) catalyze the breakdown of hydrogen peroxide and organic hydroperoxides [47, 48]. Glutathione reductase reduces GSSG and refills GSH pools [49]. Under physiological conditions, glutathione almost exclusively exists in its reduced form because of a constitutive activity of glutathione reductase in cells [50]. Glutathione S-transferases are detoxification enzymes that catalyze the conjunction of GSH to a variety of exogenous and endogenous electrophilic compounds [51-53]. GSTs are overexpressed in a wide variety of tumors to regulate MAPK pathways and are also involved in the development of resistance to chemotherapeutics[51].

\section{Signaling pathways regulated by ROS in cancer}

ROS-sensitive signaling pathways are persistently elevated in many types of cancers, where they participate in cell growth/proliferation, differentiation, protein synthesis, glucose metabolism, cell survival and inflammation [1]. Reactive oxygen species, particularly hydrogen peroxide, can act as second messengers in cellular signaling [16, 54-57]. $\mathrm{H}_{2} \mathrm{O}_{2}$ regulates protein activity through reversible oxidation of its targets including protein tyrosine phosphatases, protein tyrosine kinases, receptor tyrosine kinases and transcription factors $[1,27,58]$. In the following paragraphs, we focus on ROS-mediated regulation of the mitogen-activated protein (MAP) kinase/Erk cascade, phosphoinositide-3-kinase (PI3K)/ Akt-regulated signaling cascades, as well as the IкB kinase (IKK)/nuclear factor $\kappa-\mathrm{B}$ (NF$\kappa \mathrm{B}$ )-activating pathways (Figure 2). Other ROS-regulated signaling pathways are included in chapter 5 . 


\subsection{ROS-mediated regulation of the MAPK/Erk1/2pathway}

The activation of the MAPK (mitogen-activated protein kinase)/Erk1/2 (extracellularregulated kinase 1/2) pathway in cancer is mediated through growth factors and K-ras and was functionally linked to increased cell proliferation [59,60]. For instance, in human breast cancer cells, Erk1/2 activated by hydrogen peroxide generated as a byproduct during estrogen metabolism increases cell proliferation [61, 62]. Several mechanisms of how ROS activate Erk1/2 are known. For example Ras, which is an upstream activator for Erk1/2, can be activated directly through oxidative modification at its cysteine 118 residue, leading to the inhibition of GDP/GTP exchange [63]. ROS also activate upstream kinases of Erk1/2 such as $\mathrm{p} 90^{\mathrm{RSK}}[64,65]$. It was recently shown that increased Erk1/2 activity in ovarian cancer cells in the presence of the high concentration of endogenous ROS results from sustained ubiquitination and loss of endogenous MKP3 (mitogen-activated protein kinase phosphatase 3), a phosphatase that negatively-regulates Erk1/2 activity [64, 65].

Additionally to its effects on cell proliferation, it was also shown in multiple cancers (i.e. ovarian cancer, breast cancer, melanoma and leukemia) that the activation of Erk1/2 through ROS increases cell survival, anchorage-independent growth and motility [60, 65, 66].

While a role for ROS-activated Erk1/2 signaling in cell proliferation is well established [61, $65,67]$, its ability to regulate cancer cell survival seems to be cell type specific [64, 68, 69]. For example, treatment of MCF-7 and MDA-MB-435 breast cancer cells with ROS scavengers or inhibitors that target Erk1/2 or its upstream kinase MEK (mitogen-activated protein kinase kinase) promote apoptosis and cell adhesion [70, 71]. In an animal model for skin cancer, murine keratinocytes lacking Tiam1, an upstream activator of Erk1/2, show low levels of intracellular ROS [69]. These keratinocytes are more sensitized to apoptosis upon deprivation of EGF and insulin, implicating that Erk1/2 activation though Tiam1 and ROS is required for cell survival of skin cancer [69]. In contrast, in human pancreatic cancer and glioma cells, activation of Erk1/2 upon treatment with exogenous $\mathrm{H}_{2} \mathrm{O}_{2}$ triggers cell death and this probably is due to the high basal level of ROS in these cancer cells [72-76]. In line with these in vitro data is an in vivo study showning that ROS-mediated increase of Erk1/2 activation loop phosphorylation suppresses the growth of pancreatic tumor cell xenografts[77].

\subsection{Oxidative stress regulation of thePI $3 K / A k t$ pathway}

Akt (or protein kinase B; PKB) mediates cell survival through phosphorylation and inactivation of its substrates such as the pro-apoptotic proteins Bad, Bax, Bim or FOXO transcription factors [78-83]. In breast cancer, ROS generation during estrogen metabolism or other potential mammary carcinogens was shown to activate the PI3K/Akt signaling pathway $[84,85]$. Hydrogen peroxide generated by epithelial growth factor (EGF) in human ovarian cancer cells activates Akt and p70 S6K1, a substrate of Akt that regulates protein synthesis [86]. Moreover, the inhibition of ROS in the human pancreatic tumor cell line Panc-1 reduced the levels of phosphorylated (active) Akt and induced apoptosis [87]. Akt activity is tightly controlled by a signaling cascade that encompasses the kinases PDK-1 ( 3 'phosphoinositide-dependent kinase-1), mTOR, and PI3K as well as the phosphatase PTEN (phosphatase and tensin homolog deleted on chromosome 10). PDK-1 and mTOR regulate Akt activating phosphorylations at S473 and T308, whereas PI3K generates phosphatidylinositol-3,4,5-triphosphate $\left(\mathrm{PIP}_{3}\right)$, which serves as a membrane anchor [88]. PTEN negatively regulates $\mathrm{PIP}_{3}$ levels and thus decreases Akt activity $[89,90]$. Treating cells with exogenous hydrogen peroxide it was shown that Akt and PDK-1 can be activated by oxidative stress [91, 92]. This correlates with the observation that PTEN is reversibly inactivated by $\mathrm{H}_{2} \mathrm{O}_{2}$ [93]. Loss of PTEN increases basal levels of hydrogen peroxide and superoxide due to depletion of the expression of several antioxidant enzymes including peroxiredoxins and copper/zinc superoxide dismutase [94]. This suggests a constant 
activation of Akt through enhanced ROS production due to PTEN ablation, but also oxidative stress-mediated activation of its upstream kinases.

\subsection{ROS regulation of thelKK/NF-KB pathway}

In many cancers the transcription factor NF- $\mathrm{KB}$ is uncoupled from its normal modes of regulation and shows increased activity [95-98]. Recent studies have established a crucial role for NF- $\kappa \mathrm{B}$ in tumor cell survival, regulation of cell cycle and proliferation, cellular adhesion and development of drug resistance in cancer cells during therapy [99-101].

NF- $\kappa B$ is a redox-regulated sensor for oxidative stress [102] and is activated by low doses of hydrogen peroxide [103]. When inactive, NF- $\kappa B$ is tightly bound to its inhibitor I $\mathrm{B}$ that sequesters the transcription factor in the cytosol [104-108]. The canonical activation of NF$\kappa \mathrm{B}$ is mediated through the NF- $\kappa \mathrm{B}$-inducing kinase (NIK) and the I $\kappa \mathrm{B}$ kinase (IKK) complex, consisting of IKKa, IKK $\beta$ and NEMO. Upon its activation through cytokines such as TNFa or IL-1, NIK phosphorylates and activates its downstream targets, the kinases IKKa and IKK $\beta[104,109-111]$. Active IKKs phosphorylate I $\kappa$ B and this leads to its subsequent ubiquitination and proteosomal degradation $[112,113]$. Degradation of IKB translocates NF- $\kappa \mathrm{B}$ to nucleus, where it acts as a transcription factor to induce the expression of anti-apoptotic and anti-inflammatory genes[114].

Oxidative stress activates NF- $\kappa \mathrm{B}$ through a variety of distinct signaling pathways [115]. For example, treatment of MCF-7 breast cancer cells with TNFa, IL-1 $1 \beta$ or the mammary carcinogen sodium arsenite generates hydrogen peroxide and superoxide, which translates to the activation of NF- $\kappa \mathrm{B}$ and increased cell proliferation [116-118]. In oral squamous carcinoma cells silencing of the antioxidant superoxide dismutase (SOD) increased basal ROS levels correlating with increased NIK and NF- $\kappa$ B activity [119]. The mechanism of how ROS activates NIK is most likely via oxidative inhibition of regulatory phosphatases [116]. Recent work from our group delineated an IKK-dependent NF- $\kappa B$-inducing signaling pathway that is activated by increased cellular oxidative stress, induced either by exogenous treatment of cells with hydrogen peroxide, by rotenone-mediated mitochondrial generation of superoxide, or inhibition of intracellular antioxidant systems such as the glutathione system [120, 121]. In this pathway, NF-kB is activated through the lipase PLD1 and the kinases Src, $\mathrm{Abl}$ and Protein Kinase $\mathrm{C} \delta(\mathrm{PKC} \delta)$, whose signaling converge at the level of Protein Kinase D1 (PKD1) [120, 122-124]. PKD1 is upstream of the IKK complex and mediates the activation of NF- $\kappa \mathrm{B}$ through IKK $\beta$ [121]. In addition to this, IKK-independent activation of NF- $\kappa \mathrm{B}$ in response to ROS can occur through tyrosine phosphorylation of $\mathrm{I} \kappa \mathrm{Ba}$, leading to a release from the IKK complex but not to its degradation $[125,126]$.

\section{Specific functions of ROS in cancer}

Oxidative stress-mediated signaling events have been reported to affect all characters of cancer cell behavior $[1,2,127]$. For instance, ROS in cancer are involved in cell cycle progression and proliferation, cell survival and apoptosis, energy metabolism, cell morphology, cell-cell adhesion, cell motility, angiogenesisand maintenance of tumor stemness (Figure 3).

\subsection{ROS in tumor cell proliferation}

Low doses of hydrogen peroxide and superoxide stimulate cell proliferation in a wide variety of cancer cell types [1,128]. For example, intracellular oxidative stress in breast cancer cells is increased through the translocation of estrogen to the mitochondria [62, 129131]. Mitochondria-derived ROS regulate both cell proliferation and quiescence. This is mediated by MnSOD activity which serves as a mitochondrial ROS switch [132]. Decreased MnSOD activity favors proliferation, due to increased superoxide and low hydrogen 
peroxide levels, while increasing MnSOD activity drives the proliferating cells to transit into quiescence, due to increased generation of hydrogen peroxide [133]. In breast cancer cells, ihibition of the mitochondrial uniporter blocks ROS generation and suppresses estrogeninduced cell proliferation, suggesting a role of mitochondrial ROS in tumor growth [134]. Estrogen-induced cell proliferation results from ROS-mediated activation of the Erk1/2 MAPK signaling pathway and the transcription factorCREB (cyclic AMP response element (CRE)-binding protein) [61, 131].

Reactive oxygen species can upregulate the mRNA levels of cyclins that participate in the cell cycle to expedite $\mathrm{G} 1$ to $\mathrm{S}$ phase transition, including cyclin B2, cyclin D3, cyclin E1 and cyclin E2 [130]. It was shown that loss of the redox control of the cell cycle in normal MCF-10A cells may contribute to aberrant proliferation [135]. The treatment of MCF-10A cells with the antioxidant NAC caused delays in the progression from G1 to S accompanied with a decrease in cyclin D1 levels [135]. Further, the environmental carcinogen sodium arsenite stimulates ROS production in breast cancer cells and potentiates $S$ phase progression and subsequent cell proliferation [118]. Likewise, benzo(a)pyrene quinines (BPQs) imitate growth factor signaling and increase mammary epithelial cell growth rates through induction of superoxide and hydrogen peroxide [84].

Conversely, antioxidants inhibit tumor cell proliferation [136]. For example, pancreatic cancer cell lines generally show high basal levels of endogenous oxidative stress as compared to normal cells [1]. These increased ROS levels have been linked to increased proliferation. A stable ectopic expression of the highly-active antioxidant enzyme MnSOD reduces the cell growth rate of pancreatic tumor cells [72]. Moreover, the expression levels and activities of endogenous MnSOD, Cu/ZnSOD, catalase and glutathione peroxidase reversely correlate with cell doubling times in various pancreatic cancer cell lines [72, 73]. ATM (ataxia telangiectasia mutated) is one of the proteins involved in cell cycle regulation that are activated by ROS. Patients lacking ATM show higher levels of oxidative damage and similar effects in obtained with ATM knockout mice can be rescued with administration of antioxidants [137, 138]. Altogether, this suggests ROS as positive regulators of tumor cell proliferation by modulating key proteins in cell cycle progression.

\subsection{ROS in apoptosis and cell survival}

Disproportional increase in intracellular ROS can induce cancer cell cycle arrest, senescence and apoptosis. This can be achieved with cancer chemotherapy, depletion of cells from antioxidant proteins or generation of ROS by immune cells. Apoptosis is linked to an increase in mitochondrial oxidative stress that causes cytochrome $\mathrm{C}$ release, an unrevocable event that leads to the activation of caspases and cell death [139, 140]. Additionally, superoxide generation through the Rac-1/NADPH oxidase pathway can alsoind uce proapoptotic signaling[141].

Mitochondrial release of $\mathrm{H}_{2} \mathrm{O}_{2}$ and $\mathrm{NO}$ upon apoptotic signals leads to the activation of cJun N-terminal kinases (JNKs) $[139,142]$. In response to ROS, JNKs catalyze the phosphorylation and downregulation of anti-apoptotic proteins such as Bcl-2 and Bcl-XL [139]. Both Bcl-2 and Bcl-XL have been shown to antagonize ROS generation and to protect cells from ROS-mediated apoptosis [143, 144]. JNK also alters the composition of the Bax/Bcl-2 complex by increasing the expression of Bax, leading to formation of Bax homodimers resulting in dissipation of mitochondrial membrane integrity[145-148].

p38, another MAPK family member was also implicated in apoptotic signaling in response to increased generation of ROS. Both p38 and JNK are activated through Ask-1 (apoptosis signal-regulating kinase-1), whose activity is regulated by its interaction with thioredoxin. Thioredoxin is a redox-regulated protein that in its reduced form binds and inhibits Ask-1 
$[149,150]$. In addition to Ask-1-induced signaling cascades, other signaling proteins such as forkhead transcription factors (i.e. FOXO3a), p66Shc and p53 have been implicated in the induction of apoptosis in response to ROS [78, 151]. For example, an interesting hypothesis is that constitutive oxidative stress in tumor cells may lead to the selection of p53-deficient clones that are resistant to apoptosis [1].

Death receptors such as the TNF receptor I mainly induce ROS generation via the mitochondria, leading to caspase activation and cell death [152]. However, TRAF4 (TNF receptor-associated factor4), a component of the TNFa signaling pathway, also binds to the NADPH oxidase complex to activate JNK [153], suggesting that death receptors may use several ways to induce ROS within cells. Notably, TNF-induced oxidative stress also mediates anti-apoptotic signaling by inducing the expression of MnSOD and catalase through NF- $\kappa \mathrm{B}$ [154].

In above signaling events high levels of ROS turn on cell death signaling. However, it recently became clear that low levels of oxidative stress can also actively promote cell survival signaling. Such a ROS-mediated survival pathway is regulated by protein kinase D1 (PKD1) [120, 121, 124, 155-157]. Elevation of intracellular mitochondrial ROS levels activates PKD1 and subsequently NF- $\kappa \mathrm{B}$, leading to upregulation of antioxidant proteins such as MnSOD and anti-apoptotic proteins such as A20 and cIAPs [158]. In this pathway PKD1 is activated through the tyrosine kinase Src. Src directly phosphorylates PKD1, but also facilitates further activating phosphorylations through the kinases PKC $\delta$ (a member of the novel PKC family) and Abl [6, 120, 121, 123, 124, 142]. The elimination of this pathway sensitizes tumor cells to oxidative stress and increases their susceptibility to ROSmediated cell death $[155-157,159,160]$.

Another anti-apoptotic protein that is activated by ROS in cancer is Akt, a serine/threonine kinase that fosters cell survival through phosphorylation and inactivation of its pro-apoptotic substrates [78-83]. Akt activity is induced by multiple receptor tyrosine kinases such as PDGF-R as well as constitutively-active K-ras via activation of PI3K.

\subsection{ROS as regulators of cell motility and metastasis}

The treatment of carcinoma cells with hydrogen peroxide prior to intravenous injection into mice enhanced metastasis [161]. Additionally, subpopulations of the low- or non-motile breast cancer cell line MCF-7 that possess higher levels of endogenous ROS than the parental cells showed increased motility, and orthotopic tumors generated with these cell lines metastasized to lung, liver and spleen [162]. Furthermore, metastatic breast cancer and highly-invasive pancreatic cancer cells show lower levels and activities of the antioxidant enzyme MnSOD [73, 163, 164]. This illustrates that the intracellular redox state governs crucial steps for the metastatic process. This comprises decreased cell adhesion to extracellular matrix, anchorage-independent survival, increased migratory and invasive potential, as well as intravasation.

Cell adhesion and migration are dependent on integrin binding to extracellular matrix. Integrins elevate oxidant levels mainly by increasing cyclooxygenase-2 [165], but also through 5-lipoxygenases $(5-\mathrm{LOX})$ and mitochondria $[27,166]$. In this context, an increase in mitochondrial ROS was linked to a first cellular contact with ECM, and increases in cytosolic ROS were shown to contribute to cytoskeleton remodeling and actin stress fiber formation during a later phase of the process [27, 167]. Targets for mitochondrial ROS in these processes are SHP-2 and FAK (focal adhesion kinase), while cytosolic ROS targetthe phosphat ases LMW-PTP and SHP-2, receptor tyrosine kinases, Src-family kinases, FAK and structural proteins such as $\beta$-actin (in more detail reviewed in [27]). Activation of phosphatases and Src occurs through direct oxidation, whereas activation of FAK is 
probably indirect through upstream signaling events leading to its tyrosine phosphorylation [168]. Both Src and FAK are initiators of focal adhesion formation in adherent cells, contributing to cell spreading, cell migration and prevention of cell death by anoikis.

Non-transformed cells require an anchorage to extracellular matrix (ECM) to execute the mitotic program. In this process ROS act as key second messengers to facilitate proper mitosis [27, 169]. A synergistic signaling between growth factors (GF) and integrins leads to an oxidative burst through a Rac-1-dependent increase in mitochondrial ROS [13, 170]. This leads to oxidative inhibition of PTPs, activation of Src and other protein tyrosine kinases or structural proteins, with the net effect of increasing cell adhesion to ECM, cell spreading and proliferation. Loss of cell to matrix adhesion in non-transformed cells triggers anoikis, a specific type of apoptosis. In contrast to non-transformed cells, tumor cells are protected from this process and show increased cell proliferation and independence of anchorage. Such resistance to anoikis allows tumor cells to survive outside their "normal" environment and to metastasize and form new colonies at distant sites. The mechanism of how tumor cells become independent of cell attachment signals is most likely through increased generation of intracellular ROS. Such increase in oxidative stress seems to mimic autocrine/ adhesive signals, which in normal cells are mediated by growth factor and integrin signaling. For example, in prostate cancer cells redox-regulated anoikis resistance is mediated via Src and the EGF receptor [171]. Subsequently, this results in a constitutive deregulation of mitogenic pathways and proliferation independent of anchorage. It further allows cancer cells to abolish anoikis signals and escape apoptotic responses after a loss of cell/ECM contacts(for excellent review on this topic [27]).

Before cells migrate to distal sites, they undergo epithelial-mesenchymal transition (EMT) to release themselves from the restrain of the basal membrane. During this process, metalloproteinases (MMPs) are upregulated to degrade the proteins that compose the basal membrane. Treatment of murine mammary epithelial cells with MMP-3, a stromal protease that is upregulated in mammary tumors, increased their intracellular ROS levels (mainly $\mathrm{H}_{2} \mathrm{O}_{2}$ ) and led to EMT through induction of Rac1b RhoGTPase [172]. Moreover, application of NAC ( $N$-acetyl-L-cysteine) to remove ROS, abolished MMP-3-induced EMT [172], bolstering that MMP induces oxidative stress to lead to malignant transformation. This increase in ROS mediates oxidative damage to DNA and genomic instability. It further stimulates the expression of Snail, which previously was identified as one of the keytranscription factors regulating EMT. Other ROS-regulated genesrelevant to EMT are Ecadherin, integrinsand MMPs [173].

Activation of Rac and subsequent generation of ROS leads to NF- $\kappa$ B activation and MMP-1 production in response to integrin-mediated cell shape changes [170]. Rac-1 mediated changes in cellular ROS levels also increase the migratory potential of MCF-7 and T47D breast cancer cells probably through NF- $\kappa B$ [174]. Similarly, Rac-1 is a downstream target for c-Met and Rac-1-mediated ROS generation was involved in Met's prometastatic signaling [28]. Moreover, Rac-1 has important functions in ROS mediated actin reorganization of migrating tumor cells [175]. Multiple processes regulate actin reorganization at the leading edge of migrating cells including the actin-severing protein cofilin [176, 177]. Rac-1 activates NADPH oxidase (NOX) and ROS generated by this enzyme have been shown to activate the cofilin pathway and thus contributes to increased cell migration $[177,178]$. The tyrosine kinase Src is also regulates NADPH oxidase 1 (NOX1) induced generation of ROS [179]. NOX-1 is capable of transforming cells and is also required to maintain the transformed state [87, 174]. NOX1-mediated ROS generation has been shown to be necessary for the formation of invadopodia, actin cytoskeleton-based structures that tumor cells use to invade [180]. 
Matrix metalloproteinases facilitate the degradation and reorganization of extracellular matrix (ECM) and their increased activation was associated with primary tumor growth, angiogenesis, increased tumor cell invasion, blood vessel penetration and metastasis [181184]. ROS regulate not onlythe expression of MMPs, but also the inactivation of their inhibitors TIMP (tissue inhibitor of metalloproteinase) [185, 186]. An important step in oxidative stress-mediated expression of MMP genes is the dismutation of mitochondriallygenerated superoxide to hydrogen peroxide [187]. Hydrogen peroxide then regulates the expression of MMPs through activation of the Ras-Erk1/2-Ets (E twenty-six), Rac-1-JNKAP-1 (activating protein-1) or p38 signaling pathways [188] (for an review on this topic: [184]). Further, the redox-sensitive transcription factors NF- $\kappa B$ and FOXO3a have been described as regulators of MMP expression [1, 159]. Additionally to regulating MMP expression, ROS also can lead to the direct activation of MMPs through reaction with thiol groups in theirc atalytic domain [189].

Finally, ROS may also promote tumor cell metastasis by increasing the vascular permeability [181]. Increased activity of Rac-1 in primary endothelial cells mediates a loss of cell-cell adhesions and loosens the integrity of the endothelium, which allows the intravasation of cancer cells [190]. It was shown that reverse (basolateral-to-apical) transendothelial migration (TEM) of human melanoma cells is induced by hydrogen peroxide an can be blocked by thioredoxin [191]. Oxidative stress also regulates the expression of interleukin-8 (IL-8) and the cell surface protein ICAM-1 (intracellular adhesion protein 1, CD54) through NF- $\kappa$ B. Both ICAM-1 and IL-8 can regulate the transendothelial migration of tumor cells [192]. Further, phosphorylation of the heatshock protein Hsp27 by ROS-activated p38 induces changes in actin dynamics in vascular endothelial cells, which may contribute to facilitate invasive processes[193].

\subsection{Hypoxia as a factor leading to tumor progression}

Within a growing tumor mass cancer cells repeatedly face cycles of hypoxia and reoxygenation [194-196]. Limitations in oxygen supply due to prolonged hypoxia can result in cell death. Tumor cells can use the "Warburg effect", a metabolic switch to glycolysis, to adapt to low oxygen tension [197]. Normal and tumor cells differ significantly in energy metabolism. Glucose is the primary energy source for normal cells. Normal cells switch to anaerobic glycolysis only when adequate oxygen supply is not available and mitochondrial function is suppressed [198]. A shift from aerobic to anaerobic metabolism in tumor cells occurs even under conditions of normoxia or after mitochondrial dysfunction, oncogenic transformation or loss of tumor suppressor genes [196, 199].

The adaption of tumor cells to hypoxia contributes to the malignant phenotype and to aggressive tumor progression [200]. Hypoxia induces several transcription factors including HIF-1 (hypoxia inducible factor-1), which is composed of two subunits HIF-1a and HIF-1 $\beta$. $[196,200]$. Under normal growth conditions HIF-1 is regulated by oxygen-dependent prolyl hydroxylases (PHDs) and the VHL ubiquitin ligase, which promote its proteosomal degradation [201]. However, HIF-1 becomes transcriptionally-active under low oxygen conditions. It was shown that under hypoxic conditions MnSOD suppresses the induction of HIF-1a in human breast carcinoma cells. This suggests that superoxide may contribute to HIF-1a accumulation [133]. However, increased generation of $\mathrm{H}_{2} \mathrm{O}_{2}$ also led to accumulation of HIF-1a, suggesting that both type of ROS can increase HIF-1a levels [133]. Increased HIF-1a expression has been shown to correlate with poor prognosis and increased cancer cell invasiveness. HIF-1 regulates glycolysis-related genes and inhibits mitochondrial respiration (reviewed in [196]), resulting in hypoxic adaption of tumor cells. This leads to glycolytic ATP generation [202], reduced formation of mitochondriallygenerated $\mathrm{H}_{2} \mathrm{O}_{2}$, enhanced survival of poorly oxygenated cells and regulation of EMT- and metastasis-related genes [203]. HIF-1 also prevents intracellular acidification, which leads to 
an increased formation of lactate and $\mathrm{CO}_{2}$ [202], both favoring extracellular matrix degradation and cell invasion [204].

\subsection{Role of oxidative stress in angiogenesis}

With increased tumor growth, more nascent blood vessels are developed to facilitate oxygen and nutrient supply to the center of the tumor [205, 206]. Several lines of evidence suggest a role for ROS in augmenting angiogenesis. For example, hypoxic conditions stimulate blood vessel development, whereby the blood flow in these new vessels is often chaotic, causing oxidative stress through periods of hypoxia and reoxygenation [181]. It was shown with a mouse model for breast cancer that administration of Mn(III) ortho-tetrakis-Nethylpyridylporphyrin, a potent scavenger of reactive oxygen and nitrogen species, attenuates angiogenesis by modifying the density of microvessels and the proliferation rate of endothelial cells [207].

Angiogenesis is mediated through growth factors such as vesicular epithelial growth factor (VEGF) [208-210]. VEGF expression can be regulated by nutrient deprivation and hypoxia, which both increase intracellular levels of reactive oxygen species [211]. In such an environment HIF- 1 and its cofactor p300 initiate gene expression including the expression of VEGF [212, 213]. On the other hand, suppression of endogenous ROS by mitochondrial inhibitors or glutathione peroxidase decreases HIF-1 induction and VEGF expression in cancer cells [214]. Growth factor-mediated activation of Akt and subsequent formation of superoxide and $\mathrm{H}_{2} \mathrm{O}_{2}$ also lead to an induction of HIF-1 followed by expression of VEGF [86, 215]. This is blocked when cells are pretreated with catalase [86]. The knockdown of PTEN, a negative-regulatory phosphatase for the PI3K/Akt pathway, enhances VEGF secretion [216]. This is probably mediated by an increase in basal levels of hydrogen peroxide and superoxide, due to decreased expression of several antioxidant enzymes such as peroxiredoxins and $\mathrm{Cu} / \mathrm{ZnSOD}[94]$.

ROS-induced secretion of matrix metalloproteinases such as MMP-1 from tumor cells promotes vessel growth within the tumor microenvironment. Further, a transient expression of MMP-1, MMP-2 and MMP-9 correlates with an increase in ROS during formation of capillary-like structures, implicating that MMP-mediated angiogenesis also occurs through upregulation of ROS [217]. ROS can also trigger vasodilation to increase the blood supply of tumors through activation of heme oxygenase-1, a enzyme that generates carbon monoxide or induces the formation of nitric oxide [218].

\subsection{ROS and redox regulation in cancer stem cells}

It is well established that after chemo- or radiotherapy a small subpopulation of surviving primary cancer cells can initiate recurrence. This subpopulation of cells termed cancer stem cells (CSC) expresses stem cell markers and is highly drug resistant. CSCs utilize redoxregulatory mechanisms to promote cell survival and tolerance to treatment $[219,220]$. As previously discussed, the accumulation of ROS is thought to contribute to the conversion of normal cells to cancer cells by mediating genomic instability, oncogenic growth, ECM independency and increased motility. In contrast to cancer cells, which maintain these high ROS levels during all stages of malignancy, cancer stem cells have an increased antioxidant capacity [221]. Keeping endogenous and induced ROS at moderate levels mediates drug resistance and allows these cells to survive during treatment, resulting in both stemness and cancer-initiating capabilities. Diehn et al, recently showed that human and murine mammary epithelial cancer stem cells contain lower concentrations of ROS, specifically superoxide, than the more mature progeny, but also normal epithelial cells [222]. They further demonstrated that these differences in ROS levels are critical for maintaining stem cell function. When compared to their normal tumor cell counterparts, CSCs showed increased 
expression of a variety of enzymes that contribute to oxygen radical scavenging [222]. Particularly genes regulating or involved in glutathione synthesis, including glutathione synthetases and glutamate cysteine ligase were increased in their expression. Also increased was the expression of FOXO1, a forkhead transcription factor that was previously implicated in the regulation of other ROS scavengers such as SOD and catalase to confer resistance to oxidative stress in hematopoietic stem cells [223].

Since ROS are critical mediators of ionizing radiation-induced therapy [224, 225] the expression of antioxidants in CSCs prevented DNA damage and protected cells from irradiation-induced cell death [222]. L-S, $R$-buthionine sulphoximine (BSO)-mediated pharmacological depletion of the ROS scavenger GSH in epithelial CSC markedly decreased their clonogenicity and resulted in increased radiosensitization [222]. Consequently, CSC-enriched populations accumulated fewer single and double strand breaks in their DNA after irradiation. Due to high levels of antioxidant signaling, cancer stem cells may also not be responsive to other (chemotherapeutic) treatments that target cancer cells by increasing intracellular ROS levels. To reduce recurrence in response to conventional therapy cancer stem cells have to be additionally targeted under consideration of their unique redox status. It will be interesting to see if decreasing oxidative defenses in cancer stem cells in vivo will cause them to loose their stemness, and if a combination therapy with standard chemotherapy is effective to eliminate both, tumor and cancer stem cells.

\section{Random damaging functions of ROS}

Increased levels of reactive oxygen species can lead to "non-specific" damage of macromolecules such as DNA, proteins and lipids. Some ROS such as $\mathrm{H}_{2} \mathrm{O}_{2}$ are not very reactive towards DNA and most of the damaging effects on DNA are due to hydroxyl ions, which are generated via the Fenton reaction [226]. In this reaction transition metals such as iron and copper donate or accept free electrons during intracellular reactions and use $\mathrm{H}_{2} \mathrm{O}_{2}$ to catalyze free radical formation. Hydroxyl radicals attack DNA rapidly due to their high diffusibility which results in formation of DNA lesions including oxidized DNA bases, single strand and double strand breaks [227, 228]. DNA adducts are removed by either the base excision repair (BER) or the nuclear excision repair (NER) pathways [229]. Cells incapable to completely repair DNA lesions (i.e. due to deficient DNA repair enzymes) undergo apoptosis to ensure these mutations will not be passed on to progeny cells. However, under certain circumstances, the cells harboring DNA mutations successfully escape programmed cell death which raises a high chance for cancerous growth.

The oxidative modification of proteins by reactive species is implicated in the etiology or progression of various disorders and diseases. The major damage of ROS to proteins is modification in their amino acid residues, resulting in altered functions. Some ROS-induced modifications also increase protein carbonylation, nitration of tyrosine and phenylalanine residues, protein degradation [230], or lead to formation of cross-linked and glycated proteins $[231,232]$. The oxidized amino acid residues of proteins can influence their ability in signal transduction mechanisms. For example, irreversible oxidation of phosphatases within the catalytic sites hinders their enzymatic activity [233]. Oxidative alterations of enzymes also impact DNA repair efficiency, the fidelity of DNA polymerase during replication/synthesis and transcriptional activity, which tightly associateswith cancer onset $[1,234-236]$.

Other cellular targets of ROS are lipids. ROS react with polyunsaturated or polydesaturated fatty acids to initiate lipid peroxidation [237, 238]. Lipid oxidation generates numerous genotoxic molecules such as malondialdehyde, 2-alkenals and 4-hydroxy-2-alkenals [239, 
240]. ROS-induced lipid peroxidation can be used as a tumor marker as shown in clinical studies [241]. For example, the detection of thiobarbituric acid-reactive substances in the serum of patients with colorectal cancer indicateshigh level of lipid peroxidation.

\section{Application of ROS and antioxidants in cancer therapy and prevention}

Many chemotherapeutic strategies are designed to exuberantly-increase cellular ROS levels with the goal to induce irreparable damages subsequently resulting in tumor cell apoptosis (for a detailed review on the use of ROS in cancer therapy: [221]). Dependent on the tumor type, this can be achieved through chemotherapy or radiation therapy [1, 242-244]. For example for pancreatic cancer, to date only few treatment strategies have been proven as effective for therapy and these include combination therapy of gemcitabine with trichostatin A, epigallocate-3-gallate (EGCG), capsaicin and benzyl isothiocyanate (BITC) [148, 245249]. All of these drugs share the same mechanism, namely to elevate intracellular ROS levels to trigger apoptosis [146, 148, 250, 251]. Another compound that modulates ROS levels and is currently tested for its potential use in tumor therapy is Sulindac, a FDAapproved, non-steroidal and anti-inflammatory drug. Sulindac enhances intracellular ROS levels and renders colon and lung cancer cells more sensitive to $\mathrm{H}_{2} \mathrm{O}_{2}$-induced apoptosis [252]. In addition, Aminoflavone (5-amino-2-(4-amino-3-fluorophenyl)-6,8-difluoro-7methylchromen-4-one; AF) induces cell death in MCF-7 and MDA-MD-468 breast cancer cells, but is not toxic for nonmalignant MCF-10A breast epithelial cells [253, 254]. Upon treatment with Aminoflavone, an increase of intracellular ROS is detected correlating with increased activation of Caspase 3 and subsequent apoptosis. The inhibition of ROS generation by pretreatment of cells with N-acetyl-L-cysteine (NAC) reverses Aminoflavoneinduced cell death [254]. Several compounds such as IOA, pancratistatin (PST) and triphala (TPL) induce apoptosis of breast cancer cells through similar mechanisms as Aminoflavone, which is to increase intracellular ROS levels through dissipation of the mitochondrial membrane potential [255-260].

Mitochondrial DNA codes for several respiratory chain subunits and is more vulnerable to DNA damage than nuclear DNA. The exposure of cells to ionizing radiation can lead to mitochondrial complex II dysfunction and increase the steady state levels of reactive oxygen species and contribute to genomic instability [261]. In human cancer, mutations in mitochondrial genes, such as the gene encoding cytochrome $\mathrm{C}$ oxidase II, are associated with increased ROS generation [262]. However, the susceptibility of mitochondrial DNA to ROS-induced mutation may also be utilized for therapy. For example, chemotherapeutic treatment of cancer patients with DNA damaging agents can lead to cell death by inducing mutations in the mitochondrial DNA that increase cellular ROS to a toxic level [262].

As discussed above, when compared to normal cells, cancer cells show increased sensitivity to glucose-induced cytotoxicity and it was suggested that increased glucose metabolism in cancer cells can compensate excess metabolic production of ROS. For example, glucose metabolism inhibits apoptosis in cancer cells through redox inactivation of cytochrome $\mathrm{C}$ [263]. Therefore, it was concluded that inhibition of glucose metabolism may provide a target for selectively targeting cancer cells by enhancing their oxidative stress levels to promote cell death [264]. 2-deoxyglucose (2DG), a glucose analog that can not be metabolized, increased oxidative stress levels and caused cell death in pancreatic and prostate cancer cells [265, 266]. Moreover, this can be enhanced by additionally increasing cellular ROS levels with mitochondrial electron chain blockers [267].

Modulation of intracellular ROS levels can also be utilized to target oxidative stressmediated tumor progression. For example, a loss of cell adhesion in tumor cells and anchorage-independent survival is tightly linked to a gain of cell motility and increased 
invasiveness. Salvicine (SAL) is a compound originally identified as a topoisomerase II poison and has entered in Phase II clinical trial for cancer therapy. Treatment of invasive MDA-MB-435 breast cancer cells with SAL causes rounded cell morphology which indicates a decrease in cell adhesion [71]. The inhibition of ROS by the free radical scavenger NAC restores cell adhesion of MDA-MB-435 cells, suggesting that ROS augment their metastatic ability.

Since evidence from clinical and bench studies indicate that elevated intracellular ROS contribute to early events involved in cancer initiation and progression, an opposite approach to mediating an increase in cellular ROS levels is to use antioxidants to deplete tumor cells from ROS-induced survival signaling pathways. Such treatment may also have preventive functions. For instance, clinical studies have linked gain of oncogenic mutations in K-ras and subsequent ROS formation or pancreatic inflammation (pancreatitis) and macrophage-mediated generation of hydrogen peroxide and superoxide to events leading to an increased risk for pancreatic cancer [268-270]. Other examples are individuals with a high cancer risk due to the deficiency of inherited tumor suppressor genes such as p53 or PTEN. For these groups a treatment with antioxidants may be effective in delaying or even preventing tumor development. Depending on the therapeutic strategy, a use of antioxidants in combination therapy may have an adverse effect on anticancer drugs that act on tumor cells by increasing ROS levels to induce cell death. However, a combination therapy with antioxidants and therapeutics that induce apoptosis independent of oxidative stress may be effective. Antioxidants under development for clinical use are for example the SOD mimetic EUK-134 [271] or a mimetic of glutathione disulfide named NOV-002 [272].

In conclusion, to tailor specific combination therapy and to decide which strategy to use, chemotherapeutics that excessively increase intracellular ROS to reach a toxic level, or antioxidants, may be dependent on the tumor type and stage, the type and level of endogenous ROSas well as abundance of ROS-induced survival pathways.

\section{Summary}

After malignant transformation many cancer cells show a sustained increase in intrinsic generation of reactive oxygen species which maintains the oncogenic phenotype and drives tumor progression. Redox adaption through upregulation of anti-apoptotic and antioxidant molecules allows cancer cells to promote survival and to develop resistance to anticancer drugs. Little is known how an increase in intracellular oxidative stress levels is sensed and transduced into ROS-induced specific intracellular signaling to regulate the expression of antioxidant and survival genes [142]. The dependence of tumor cells and cancer stem cells on their antioxidant capacity makes them vulnerable to agents that dampen antioxidant systems. There is a realistic prospect for treatments aimed to dramatically increase intracellular ROS to kill cancer cells by decreasing their antioxidant capacity [1]. This may be obtained using compounds that inhibit antioxidant systems or through inhibition of specific signaling pathways that upregulate antioxidants in cancer cells. The resulting increase in reactive oxygen species then may induce tumor cell death either through random damaging functions of ROS or by specific induction of apoptosis via death signaling pathways. The advantage of such a strategy is that normal cells are not significantly affected since they have lower basal ROS levels and therefore are less dependent on antioxidants. However, it is possible that a threshold of toxicity in these cancer cells is not reached and that the additional increase in ROS further causes more mutations or drives cell migration and invasion [221,273]. Therefore, a combination of inhibitors of antioxidant systems with pharmacological agents with pro-oxidant properties to increase ROS levels within tumor cells may be needed to overwhelm antioxidant systems over the threshold of toxicity [1, 221]. It becomes evident that a much more detailed understanding of ROS-mediated 
signaling intumor cells is necessaryto develop new strategies for such a redox modulationbased therapeutic intervention to selectively kill cancer cells and overcome drug resistance.

\section{Acknowledgments}

The authors would like to thank Heike Döppler for critical reading of the manuscript. Research in the Storz laboratory is supported by grants from the Mayo Clinic SPORE for Pancreatic Cancer (P50 CA102701), the Mayo Clinic Breast Cancer SPORE (CA116201-03DR4), an AACR-PANCAN Career development grant (08-20-25STOR), a R21 from the NCI (CA135102) as well as a Bankhead-Coley grant (FLA07BN-08) from the Florida Department of Health.

\section{Abbreviations}

5-LOX

AP-1

Ask-1

BER

BITC

BPQ

CREB

CSC

ECM

EGCG

EGF

EMT

Erk1/2

Ets

FAK

FGF

GCS

GPX

GSH

GSSG

GST

HIF-1

ICAM-1

IFN $\gamma$

IKK

IL

IOA

JNK

\section{5-Lipoxygenase}

activating protein-1

apoptosis signal-regulating kinase-1

base excision repair

benzyl isothiocyanate

benzo(a)pyrene quinines

cyclic AMP response element (CRE)-binding protein

cancer stem cell

extracellular matrix

epigallocate-3-gallate

epidermal growth factor

epithelial-to-mesenchymal transition

extracellular-regulated kinase $1 / 2$

E twenty-six

focal adhesion kinase

fibroblast growth factor

glutamylcysteine synthetase

glutathione peroxidase

glutathione

glutathione disulfide

glutathione S-transferase

hypoxia inducible factor-1

intracellular adhesion protein 1

interferon $\gamma$

$\mathrm{I} \kappa \mathrm{B}$ kinase

interleukin

isoobtusilactone $\mathrm{A}$

c-Jun $\mathrm{N}$-terminal kinase 
MAPK mitogen-activated protein kinase

MEK mitogen-activated protein kinase kinase

MKP3 mitogen-activated protein kinase phosphatase 3

MMP matrix metalloproteinase

NAC $N$-acetyl-L-cysteine

NER nuclear excision repair

$\mathbf{N F}-\kappa \mathbf{B} \quad$ nuclear factor $\kappa-\mathrm{B}$

NIK NF- $\kappa$ B-inducing kinase

PDGF platelet-derived growth factor

PDK-1 3'-phosphoinositide-dependent kinase-1

PDTC pyrrolidine dithiocarbamate

PI3K phosphoinositide 3-kinase

PKB protein kinase B

PKC protein kinase C

PKD protein kinase D

Prx peroxiredoxin

PST pancratistatin

PTEN phosphatase and tensin homolog deleted on chromosome 10

ROS reactive oxygen species

SAL salvicine

SOD superoxide dismutase

TGF $\beta$ transforming growth factor $\beta$

TIMP tissue inhibitor of metalloproteinase

TNFa tumor necrosis factor a

TPL triphala

TRAF TNF receptor-associated factor

VEGF vesicular epithelial growth factor

\section{References}

1. Storz P. Reactive oxygen species in tumor progression. Front Biosci. 2005; 10:1881-96. [PubMed: 15769673]

2. Szatrowski TP, Nathan CF. Production of large amounts of hydrogen peroxide by human tumor cells. Cancer Res. 1991; 51(3):794-8. [PubMed: 1846317]

3. Babio BM. NADPH oxidase: an update. Blood. 1999; 93(5):1464-76. [PubMed: 10029572]

4. Ha D, Williams E, Cadenas E. Mitochondrial respiratory chain-dependent generation of superoxide anion and its release into the intermembrane space. Biochem J. 2001; 353(Pt 2):411-6. [PubMed: 11139407]

5. Crompto M. The mitochondrial permeability transition pore and its role in cell death. Biochem J. 1999; 341 (Pt 2):233-49. [PubMed: 10393078] 
6. Stor P. Reactive oxygen species-mediated mitochondria-to-nucleus signaling: a key to aging and radical-caused diseases. Sci STKE. 2006; 2006(332):re3. [PubMed: 16639035]

7. Biener GP, et al. Specific aquaporins facilitate the diffusion of hydrogen peroxide across membranes. J Biol Chem. 2007; 282(2):1183-92. [PubMed: 17105724]

8. Le WK, Thevenod F. A role for mitochondrial aquaporins in cellular life-and-death decisions? Am J Physiol Cell Physiol. 2006; 291(2):C195-202. [PubMed: 16624989]

9. Danse TB, Wirtz KW. The peroxisome in oxidative stress. IUBMB Life. 2001; 51 (4):223-30. [PubMed: 11569916]

10. del Rio LA, et al. Metabolism of oxygen radicals in peroxisomes and cellular implications. Free Radic Biol Med. 1992; 13(5):557-80. [PubMed: 1334030]

11. Singh I. Mammalian peroxisomes: metabolism of oxygen and reactive oxygen species. Ann N Y Acad Sci. 1996; 804:612-27. [PubMed: 8993576]

12. Bonekamp NA, et al. Reactive oxygen species and peroxisomes: struggling for balance. Biofactors. 2009; 35(4):346-55. [PubMed: 19459143]

13. Bae YS, et al. Platelet-derived growth factor-induced $\mathrm{H}(2) \mathrm{O}(2)$ production requires the activation of phosphatidylinositol 3-kinase. J Biol Chem. 2000; 275(14):10527-31. [PubMed: 10744745]

14. Burdon RH. Superoxide and hydrogen peroxide in relation to mammalian cell proliferation. Free Radic Biol Med. 1995; 18(4):775-94. [PubMed: 7750801]

15. Goustin AS, et al. Growth factors and cancer. Cancer Res. 1986; 46(3):1015-29. [PubMed: 3002607]

16. Sundaresan $\mathrm{M}$, et al. Requirement for generation of $\mathrm{H} 2 \mathrm{O} 2$ for platelet-derived growth factor signal transduction. Science. 1995; 270(5234):296-9. [PubMed: 7569979]

17. Tiku ML, Liesch JB, Robertson FM. Production of hydrogen peroxide by rabbit articular chondrocytes. Enhancement by cytokines. J Immunol. 1990; 145(2):690-6. [PubMed: 2114447]

18. Lo YY, Cruz TF. Involvement of reactive oxygen species in cytokine and growth factor induction of c-fos expression in chondrocytes. J Biol Chem. 1995; 270(20):11727-30. [PubMed: 7744816]

19. Meier B, et al. Human fibroblasts release reactive oxygen species in response to interleukin-1 or tumour necrosis factor-alpha. Biochem J. 1989; 263(2):539-45. [PubMed: 2556998]

20. Roy D, Sarkar S, Felty Q. Levels of IL-1 beta control stimulatory/inhibitory growth of cancer cells. Front Biosci. 2006; 11:889-98. [PubMed: 16146780]

21. Ohba M, et al. Production of hydrogen peroxide by transforming growth factor-beta 1 and its involvement in induction of egr-1 in mouse osteoblastic cells. J Cell Biol. 1994; 126(4):1079-88. [PubMed: 8051207]

22. Chen Q, Olashaw N, Wu J. Participation of reactive oxygen species in the lysophosphatidic acidstimulated mitogen-activated protein kinase kinase activation pathway. J Biol Chem. 1995; 270(48):28499-502. [PubMed: 7499358]

23. Griendling KK, et al. Angiotensin II stimulates NADH and NADPH oxidase activity in cultured vascular smooth muscle cells. Circ Res. 1994; 74(6):1141-8. [PubMed: 8187280]

24. Aunoble B, et al. Major oncogenes and tumor suppressor genes involved in epithelial ovarian cancer (review). Int J Oncol. 2000; 16(3):567-76. [PubMed: 10675491]

25. Minamoto T, Mai M, Ronai Z. K-ras mutation: early detection in molecular diagnosis and risk assessment of colorectal, pancreas, and lung cancers--a review. Cancer Detect Prev. 2000; 24(1): 1-12. [PubMed: 10757118]

26. Minamoto T, Ougolkov AV, Mai M. Detection of oncogenes in the diagnosis of cancers with active oncogenic signaling. Expert Rev Mol Diagn. 2002; 2(6):565-75. [PubMed: 12465453]

27. Chiarugi P, Fiaschi T. Redox signalling in anchorage-dependent cell growth. Cell Signal. 2007; 19(4):672-82. [PubMed: 17204396]

28. Ferraro D, et al. Pro-metastatic signaling by c-Met through RAC-1 and reactive oxygen species (ROS). Oncogene. 2006; 25(26):3689-98. [PubMed: 16462764]

29. Shin EA, et al. Arachidonic acid induces the activation of the stress-activated protein kinase, membrane ruffling and $\mathrm{H} 2 \mathrm{O} 2$ production via a small GTPase Rac1. FEBS Lett. 1999; 452(3):3559. [PubMed: 10386621] 
30. Balkwill F. Tumour necrosis factor and cancer. Nat Rev Cancer. 2009; 9(5):361-71. [PubMed: 19343034]

31. Berasain C, et al. Inflammation and liver cancer: new molecular links. Ann N Y Acad Sci. 2009; 1155:206-21. [PubMed: 19250206]

32. Xiao H, Yang CS. Combination regimen with statins and NSAIDs: a promising strategy for cancer chemoprevention. Int J Cancer. 2008; 123(5):983-90. [PubMed: 18548583]

33. Babior BM. The respiratory burst oxidase. Curr Opin Hematol. 1995; 2(1):55-60. [PubMed: 9371972]

34. Segal AW, Shatwell KP. The NADPH oxidase of phagocytic leukocytes. Ann N Y Acad Sci. 1997; 832:215-22. [PubMed: 9704049]

35. Cui S, et al. Activated murine macrophages induce apoptosis in tumor cells through nitric oxidedependent or -independent mechanisms. Cancer Res. 1994; 54(9):2462-7. [PubMed: 8162595]

36. Copin JC, Gasche Y, Chan PH. Overexpression of copper/zinc superoxide dismutase does not prevent neonatal lethality in mutant mice that lack manganese superoxide dismutase. Free Radic Biol Med. 2000; 28(10):1571-6. [PubMed: 10927183]

37. Bendayan M, Reddy JK. Immunocytochemical localization of catalase and heat-labile enoyl-CoA hydratase in the livers of normal and peroxisome proliferator-treated rats. Lab Invest. 1982; 47(4): 364-9. [PubMed: 7120922]

38. Hashimoto F, Hayashi H. Significance of catalase in peroxisomal fatty acyl-CoA beta-oxidation: NADH oxidation by acetoacetyl-CoA and H2O2. J Biochem. 1990; 108(3):426-31. [PubMed: 2277034]

39. Litwin JA, et al. Immunocytochemical localization of peroxisomal enzymes in human liver biopsies. Am J Pathol. 1987; 128(1):141-50. [PubMed: 2886050]

40. Hofmann B, Hecht HJ, Flohe L. Peroxiredoxins. Biol Chem. 2002; 383(3-4):347-64. [PubMed: 12033427]

41. Rhee SG, et al. A family of novel peroxidases, peroxiredoxins. Biofactors. 1999; 10(2-3):207-9. [PubMed: 10609884]

42. Wood ZA, et al. Structure, mechanism and regulation of peroxiredoxins. Trends Biochem Sci. 2003; 28(1):32-40. [PubMed: 12517450]

43. Neumann CA, et al. Essential role for the peroxiredoxin Prdx 1 in erythrocyte antioxidant defence and tumour suppression. Nature. 2003; 424(6948):561-5. [PubMed: 12891360]

44. Holmgren A. Thioredoxin structure and mechanism: conformational changes on oxidation of the active-site sulfhydryls to a disulfide. Structure. 1995; 3(3):239-43. [PubMed: 7788289]

45. Arner ES, Holmgren A. Physiological functions of thioredoxin and thioredoxin reductase. Eur J Biochem. 2000; 267(20):6102-9. [PubMed: 11012661]

46. Mustacich D, Powis G. Thioredoxin reductase. Biochem J. 2000; 346(Pt 1):1-8. [PubMed: 10657232]

47. Brigelius-Flohe R. Tissue-specific functions of individual glutathione peroxidases. Free Radic Biol Med. 1999; 27(9-10):951-65. [PubMed: 10569628]

48. Ursini F, et al. Diversity of glutathione peroxidases. Methods Enzymol. 1995; 252:38-53. [PubMed: 7476373]

49. Carlberg I, Mannervik B. Purification and characterization of the flavoenzyme glutathione reductase from rat liver. J Biol Chem. 1975; 250(14):5475-80. [PubMed: 237922]

50. Beutler E. Effect of flavin compounds on glutathione reductase activity: in vivo and in vitro studies. J Clin Invest. 1969; 48(10):1957-66. [PubMed: 5822598]

51. Townsend DM, Tew KD. The role of glutathione-S-transferase in anti-cancer drug resistance. Oncogene. 2003; 22(47):7369-75. [PubMed: 14576844]

52. Sharma R, et al. Antioxidant role of glutathione S-transferases: protection against oxidant toxicity and regulation of stress-mediated apoptosis. Antioxid Redox Signal. 2004; 6(2):289-300. [PubMed: 15025930]

53. Hayes JD, Flanagan JU, Jowsey IR. Glutathione transferases. Annu Rev Pharmacol Toxicol. 2005; 45:51-88. [PubMed: 15822171] 
54. Colavitti R, et al. Reactive oxygen species as downstream mediators of angiogenic signaling by vascular endothelial growth factor receptor-2/KDR. J Biol Chem. 2002; 277(5):3101-8. [PubMed: $11719508]$

55. Finkel T. Redox-dependent signal transduction. FEBS Lett. 2000; 476(1-2):52-4. [PubMed: 10878249]

56. Hensley K, Floyd RA. Reactive oxygen species and protein oxidation in aging: a look back, a look ahead. Arch Biochem Biophys. 2002; 397(2):377-83. [PubMed: 11795897]

57. Irani K. Oxidant signaling in vascular cell growth, death, and survival: a review of the roles of reactive oxygen species in smooth muscle and endothelial cell mitogenic and apoptotic signaling. Circ Res. 2000; 87(3):179-83. [PubMed: 10926866]

58. Rhee SG, et al. Hydrogen peroxide: a key messenger that modulates protein phosphorylation through cysteine oxidation. Sci STKE. 2000; 2000(53):pe1. [PubMed: 11752613]

59. Khavari TA, Rinn J. Ras/Erk MAPK signaling in epidermal homeostasis and neoplasia. Cell Cycle. 2007; 6(23):2928-31. [PubMed: 18000402]

60. Roberts PJ, Der CJ. Targeting the Raf-MEK-ERK mitogen-activated protein kinase cascade for the treatment of cancer. Oncogene. 2007; 26(22):3291-310. [PubMed: 17496923]

61. Irani K, et al. Mitogenic signaling mediated by oxidants in Ras-transformed fibroblasts. Science. 1997; 275(5306):1649-52. [PubMed: 9054359]

62. Reddy KB, Glaros S. Inhibition of the MAP kinase activity suppresses estrogen-induced breast tumor growth both in vitro and in vivo. Int J Oncol. 2007; 30(4):971-5. [PubMed: 17332937]

63. Lander HM, et al. A molecular redox switch on p21(ras). Structural basis for the nitric oxidep21(ras) interaction. J Biol Chem. 1997; 272(7):4323-6. [PubMed: 9020151]

64. Chan DW, et al. Loss of MKP3 mediated by oxidative stress enhances tumorigenicity and chemoresistance of ovarian cancer cells. Carcinogenesis. 2008; 29(9):1742-50. [PubMed: 18632752]

65. McCubrey JA, et al. Roles of the Raf/MEK/ERK pathway in cell growth, malignant transformation and drug resistance. Biochim Biophys Acta. 2007; 1773(8):1263-84. [PubMed: 17126425]

66. Steelman LS, et al. Contributions of the Raf/MEK/ERK, PI3K/PTEN/Akt/mTOR and Jak/STAT pathways to leukemia. Leukemia. 2008; 22(4):686-707. [PubMed: 18337767]

67. Kumar B, et al. Oxidative stress is inherent in prostate cancer cells and is required for aggressive phenotype. Cancer Res. 2008; 68(6):1777-85. [PubMed: 18339858]

68. Lee WC, et al. Role of ERK in hydrogen peroxide-induced cell death of human glioma cells. Neurochem Res. 2005; 30(2):263-70. [PubMed: 15895830]

69. Rygiel TP, et al. The Rac activator Tiam1 prevents keratinocyte apoptosis by controlling ROSmediated ERK phosphorylation. J Cell Sci. 2008; 121(Pt 8):1183-92. [PubMed: 18349077]

70. Ostrakhovitch EA, Cherian MG. Inhibition of extracellular signal regulated kinase (ERK) leads to apoptosis inducing factor (AIF) mediated apoptosis in epithelial breast cancer cells: the lack of effect of ERK in p53 mediated copper induced apoptosis. J Cell Biochem. 2005; 95(6):1120-34. [PubMed: 15880691]

71. Zhou J, et al. Salvicine inactivates beta 1 integrin and inhibits adhesion of MDA-MB-435 cells to fibronectin via reactive oxygen species signaling. Mol Cancer Res. 2008; 6(2):194-204. [PubMed: 18314480]

72. Cullen JJ, et al. The role of manganese superoxide dismutase in the growth of pancreatic adenocarcinoma. Cancer Res. 2003; 63(6):1297-303. [PubMed: 12649190]

73. Lewis A, et al. Metastatic progression of pancreatic cancer: changes in antioxidant enzymes and cell growth. Clin Exp Metastasis. 2005; 22(7):523-32. [PubMed: 16475022]

74. Mazzio EA, Soliman KF. Glioma cell antioxidant capacity relative to reactive oxygen species produced by dopamine. J Appl Toxicol. 2004; 24(2):99-106. [PubMed: 15052604]

75. Zhang Y, et al. Overexpression of copper zinc superoxide dismutase suppresses human glioma cell growth. Cancer Res. 2002; 62(4):1205-12. [PubMed: 11861405]

76. Osada S, et al. Extracellular signal-regulated kinase phosphorylation due to menadione-induced arylation mediates growth inhibition of pancreas cancer cells. Cancer Chemother Pharmacol. 2008; 62(2):315-20. [PubMed: 17922126] 
77. Shi Y, Sahu RP, Srivastava SK. Triphala inhibits both in vitro and in vivo xenograft growth of pancreatic tumor cells by inducing apoptosis. BMC Cancer. 2008; 8:294. [PubMed: 18847491]

78. Brunet A, et al. Akt promotes cell survival by phosphorylating and inhibiting a Forkhead transcription factor. Cell. 1999; 96(6):857-68. [PubMed: 10102273]

79. Pastorino JG, Tafani M, Farber JL. Tumor necrosis factor induces phosphorylation and translocation of BAD through a phosphatidylinositide-3-OH kinase-dependent pathway. J Biol Chem. 1999; 274(27):19411-6. [PubMed: 10383455]

80. Xin M, Deng X. Nicotine inactivation of the proapoptotic function of Bax through phosphorylation. J Biol Chem. 2005; 280(11):10781-9. [PubMed: 15642728]

81. Kawamura N, et al. Akt1 in osteoblasts and osteoclasts controls bone remodeling. PLoS One. 2007; 2(10):e1058. [PubMed: 17957242]

82. Qi XJ, Wildey GM, Howe PH. Evidence that Ser87 of BimEL is phosphorylated by Akt and regulates BimEL apoptotic function. J Biol Chem. 2006; 281(2):813-23. [PubMed: 16282323]

83. Limaye V, et al. Sphingosine kinase-1 enhances endothelial cell survival through a PECAM-1dependent activation of PI-3K/Akt and regulation of Bcl-2 family members. Blood. 2005; 105(8): 3169-77. [PubMed: 15632208]

84. Burdick AD, et al. Benzo(a)pyrene quinones increase cell proliferation, generate reactive oxygen species, and transactivate the epidermal growth factor receptor in breast epithelial cells. Cancer Res. 2003; 63(22):7825-33. [PubMed: 14633709]

85. Park SA, et al. 4-hydroxyestradiol induces anchorage-independent growth of human mammary epithelial cells via activation of IkappaB kinase: potential role of reactive oxygen species. Cancer Res. 2009; 69(6):2416-24. [PubMed: 19276383]

86. Liu LZ, et al. Reactive oxygen species regulate epidermal growth factor-induced vascular endothelial growth factor and hypoxia-inducible factor-1alpha expression through activation of AKT and P70S6K1 in human ovarian cancer cells. Free Radic Biol Med. 2006; 41(10):1521-33. [PubMed: 17045920]

87. Mochizuki T, et al. Inhibition of NADPH oxidase 4 activates apoptosis via the AKT/apoptosis signal-regulating kinase 1 pathway in pancreatic cancer PANC-1 cells. Oncogene. 2006; 25(26): 3699-707. [PubMed: 16532036]

88. Storz P, Toker A. 3'-phosphoinositide-dependent kinase-1 (PDK-1) in PI 3-kinase signaling. Front Biosci. 2002; 7:d886-902. [PubMed: 11897568]

89. Ogg S, Ruvkun G. The C. elegans PTEN homolog, DAF-18, acts in the insulin receptor-like metabolic signaling pathway. Mol Cell. 1998; 2(6):887-93. [PubMed: 9885576]

90. Sun $\mathrm{H}$, et al. PTEN modulates cell cycle progression and cell survival by regulating phosphatidylinositol 3,4,5,-trisphosphate and Akt/protein kinase B signaling pathway. Proc Natl Acad Sci U S A. 1999; 96(11):6199-204. [PubMed: 10339565]

91. Higaki Y, et al. Oxidative stress stimulates skeletal muscle glucose uptake through a phosphatidylinositol 3-kinase-dependent pathway. Am J Physiol Endocrinol Metab. 2008; 294(5):E889-97. [PubMed: 18303121]

92. Prasad N, et al. Oxidative stress and vanadate induce tyrosine phosphorylation of phosphoinositide-dependent kinase 1 (PDK1). Biochemistry. 2000; 39(23):6929-35. [PubMed: 10841774]

93. Lee SR, et al. Reversible inactivation of the tumor suppressor PTEN by H2O2. J Biol Chem. 2002; 277(23):20336-42. [PubMed: 11916965]

94. Huo YY, et al. PTEN deletion leads to deregulation of antioxidants and increased oxidative damage in mouse embryonic fibroblasts. Free Radic Biol Med. 2008; 44(8):1578-91. [PubMed: 18275859]

95. Basseres DS, Baldwin AS. Nuclear factor-kappaB and inhibitor of kappaB kinase pathways in oncogenic initiation and progression. Oncogene. 2006; 25(51):6817-30. [PubMed: 17072330]

96. Biswas DK, Iglehart JD. Linkage between EGFR family receptors and nuclear factor kappaB (NFkappaB) signaling in breast cancer. J Cell Physiol. 2006; 209(3):645-52. [PubMed: 17001676]

97. Biswas DK, et al. NF-kappa B activation in human breast cancer specimens and its role in cell proliferation and apoptosis. Proc Natl Acad Sci U S A. 2004; 101(27):10137-42. [PubMed: 15220474] 
98. Rayet B, Gelinas C. Aberrant rel/nfkb genes and activity in human cancer. Oncogene. 1999; 18(49):6938-47. [PubMed: 10602468]

99. Ahmed KM, Cao N, Li JJ. HER-2 and NF-kappaB as the targets for therapy-resistant breast cancer. Anticancer Res. 2006; 26(6B):4235-43. [PubMed: 17201139]

100. Bourguignon LY, Xia W, Wong G. Hyaluronan-mediated CD44 interaction with p300 and SIRT1 regulates beta-catenin signaling and NFkappaB-specific transcription activity leading to MDR1 and Bcl-xL gene expression and chemoresistance in breast tumor cells. J Biol Chem. 2009; 284(5):2657-71. [PubMed: 19047049]

101. Duffey DC, et al. Inhibition of transcription factor nuclear factor-kappaB by a mutant inhibitorkappaBalpha attenuates resistance of human head and neck squamous cell carcinoma to TNFalpha caspase-mediated cell death. Br J Cancer. 2000; 83(10):1367-74. [PubMed: 11044363]

102. Li N, Karin M. Is NF-kappaB the sensor of oxidative stress? Faseb J. 1999; 13(10):1137-43. [PubMed: 10385605]

103. Schreck R, Albermann K, Baeuerle PA. Nuclear factor kappa B: an oxidative stress-responsive transcription factor of eukaryotic cells (a review). Free Radic Res Commun. 1992; 17(4):221-37. [PubMed: 1473734]

104. Beg AA, et al. Tumor necrosis factor and interleukin-1 lead to phosphorylation and loss of I kappa B alpha: a mechanism for NF-kappa B activation. Mol Cell Biol. 1993; 13 (6):3301-10. [PubMed: 8497253]

105. Beg AA, et al. I kappa B interacts with the nuclear localization sequences of the subunits of NFkappa B: a mechanism for cytoplasmic retention. Genes Dev. 1992; 6(10):1899-913. [PubMed: 1340770]

106. Bonizzi G, et al. Activation of IKKalpha target genes depends on recognition of specific kappaB binding sites by RelB:p52 dimers. Embo J. 2004; 23(21):4202-10. [PubMed: 15470505]

107. Delhase M, et al. Positive and negative regulation of IkappaB kinase activity through IKKbeta subunit phosphorylation. Science. 1999; 284(5412):309-13. [PubMed: 10195894]

108. Hacker H, Karin M. Regulation and function of IKK and IKK-related kinases. Sci STKE. 2006; 2006(357):re13. [PubMed: 17047224]

109. Bergmann M, et al. IkappaBalpha degradation and nuclear factor-kappaB DNA binding are insufficient for interleukin-1beta and tumor necrosis factor-alpha-induced kappaB-dependent transcription. Requirement for an additional activation pathway. J Biol Chem. 1998; 273(12): 6607-10. [PubMed: 9506955]

110. Claudio E, et al. Molecular mechanisms of TNFalpha cytotoxicity: activation of NF-kappaB and nuclear translocation. Exp Cell Res. 1996; 224(1):63-71. [PubMed: 8612692]

111. Ling L, Cao Z, Goeddel DV. NF-kappaB-inducing kinase activates IKK-alpha by phosphorylation of Ser-176. Proc Natl Acad Sci U S A. 1998; 95(7):3792-7. [PubMed: 9520446]

112. Ghoda L, Lin X, Greene WC. The 90-kDa ribosomal S6 kinase (pp90rsk) phosphorylates the Nterminal regulatory domain of IkappaBalpha and stimulates its degradation in vitro. J Biol Chem. 1997; 272(34):21281-8. [PubMed: 9261139]

113. Singh S, Darnay BG, Aggarwal BB. Site-specific tyrosine phosphorylation of IkappaBalpha negatively regulates its inducible phosphorylation and degradation. J Biol Chem. 1996; 271(49): 31049-54. [PubMed: 8940099]

114. Karin M. The IkappaB kinase - a bridge between inflammation and cancer. Cell Res. 2008; 18(3): 334-42. [PubMed: 18301380]

115. Janssen-Heininger YM, Poynter ME, Baeuerle PA. Recent advances towards understanding redox mechanisms in the activation of nuclear factor kappaB. Free Radic Biol Med. 2000; 28(9):131727. [PubMed: 10924851]

116. Li Q, Engelhardt JF. Interleukin-1beta induction of NFkappaB is partially regulated by $\mathrm{H} 2 \mathrm{O} 2$ mediated activation of NFkappaB-inducing kinase. J Biol Chem. 2006; 281(3):1495-505. [PubMed: 16286467]

117. Manna SK, et al. Overexpression of manganese superoxide dismutase suppresses tumor necrosis factor-induced apoptosis and activation of nuclear transcription factor-kappaB and activated protein-1. J Biol Chem. 1998; 273(21):13245-54. [PubMed: 9582369] 
118. Ruiz-Ramos R, et al. Sodium arsenite induces ROS generation, DNA oxidative damage, HO-1 and c-Myc proteins, NF-kappaB activation and cell proliferation in human breast cancer MCF-7 cells. Mutat Res. 2009; 674(1-2):109-15. [PubMed: 18996220]

119. Wang Y, et al. The endogenous reactive oxygen species promote NF-kappaB activation by targeting on activation of NF-kappaB-inducing kinase in oral squamous carcinoma cells. Free Radic Res. 2007; 41 (9):963-71. [PubMed: 17729113]

120. Storz P, Doppler H, Toker A. Protein kinase Cdelta selectively regulates protein kinase Ddependent activation of NF-kappaB in oxidative stress signaling. Mol Cell Biol. 2004; 24(7): 2614-26. [PubMed: 15024053]

121. Storz P, Toker A. Protein kinase D mediates a stress-induced NF-kappaB activation and survival pathway. Embo J. 2003; 22(1):109-20. [PubMed: 12505989]

122. Cowell CF, et al. Mitochondrial diacylglycerol initiates protein-kinase D1-mediated ROS signaling. J Cell Sci. 2009; 122(Pt 7):919-28. [PubMed: 19258390]

123. Doppler H, Storz P. A novel tyrosine phosphorylation site in protein kinase D contributes to oxidative stress-mediated activation. J Biol Chem. 2007; 282(44):31873-81. [PubMed: 17804414]

124. Storz P, Doppler H, Toker A. Activation loop phosphorylation controls protein kinase Ddependent activation of nuclear factor kappaB. Mol Pharmacol. 2004; 66(4):870-9. [PubMed: 15226414]

125. Imbert V, et al. Tyrosine phosphorylation of I kappa B-alpha activates NF-kappa B without proteolytic degradation of I kappa B-alpha. Cell. 1996; 86(5):787-98. [PubMed: 8797825]

126. Mukhopadhyay A, Manna SK, Aggarwal BB. Pervanadate-induced nuclear factor-kappaB activation requires tyrosine phosphorylation and degradation of IkappaBalpha. Comparison with tumor necrosis factor-alpha. J Biol Chem. 2000; 275(12):8549-55. [PubMed: 10722693]

127. Gupta A, Rosenberger SF, Bowden GT. Increased ROS levels contribute to elevated transcription factor and MAP kinase activities in malignantly progressed mouse keratinocyte cell lines. Carcinogenesis. 1999; 20(11):2063-73. [PubMed: 10545407]

128. Burdon RH, Gill V, Rice-Evans C. Oxidative stress and tumour cell proliferation. Free Radic Res Commun. 1990; 11(1-3):65-76. [PubMed: 1963620]

129. Felty Q, Roy D. Estrogen, mitochondria, and growth of cancer and non-cancer cells. J Carcinog. 2005; 4(1):1. [PubMed: 15651993]

130. Felty Q, Singh KP, Roy D. Estrogen-induced G1/S transition of G0-arrested estrogen-dependent breast cancer cells is regulated by mitochondrial oxidant signaling. Oncogene. 2005; 24(31): 4883-93. [PubMed: 15897899]

131. Felty Q, et al. Estrogen-induced mitochondrial reactive oxygen species as signal-transducing messengers. Biochemistry. 2005; 44(18):6900-9. [PubMed: 15865435]

132. Sarsour EH, et al. Manganese superoxide dismutase activity regulates transitions between quiescent and proliferative growth. Aging Cell. 2008; 7(3):405-17. [PubMed: 18331617]

133. Wang M, et al. Manganese superoxide dismutase suppresses hypoxic induction of hypoxiainducible factor-1alpha and vascular endothelial growth factor. Oncogene. 2005; 24 (55):815466. [PubMed: 16170370]

134. Parkash J, Felty Q, Roy D. Estrogen exerts a spatial and temporal influence on reactive oxygen species generation that precedes calcium uptake in high-capacity mitochondria: implications for rapid nongenomic signaling of cell growth. Biochemistry. 2006; 45(9):2872-81. [PubMed: 16503642]

135. Menon SG, et al. Differential susceptibility of nonmalignant human breast epithelial cells and breast cancer cells to thiol antioxidant-induced G(1)-delay. Antioxid Redox Signal. 2005; 7(5-6): 711-8. [PubMed: 15890017]

136. Behrend L, Henderson G, Zwacka RM. Reactive oxygen species in oncogenic transformation. Biochem Soc Trans. 2003; 31(Pt 6):1441-4. [PubMed: 14641084]

137. Browne SE, et al. Treatment with a catalytic antioxidant corrects the neurobehavioral defect in ataxia-telangiectasiamice. Free Radic Biol Med. 2004; 36(7):938-42. [PubMed: 15019978]

138. Reichenbach J, et al. Elevated oxidative stress in patients with ataxia telangiectasia. Antioxid Redox Signal. 2002; 4(3):465-9. [PubMed: 12215213] 
139. Cadenas E. Mitochondrial free radical production and cell signaling. Mol Aspects Med. 2004; 25(1-2):17-26. [PubMed: 15051313]

140. Simon HU, Haj-Yehia A, Levi-Schaffer F. Role of reactive oxygen species (ROS) in apoptosis induction. Apoptosis. 2000; 5(5):415-8. [PubMed: 11256882]

141. Chung YM, Bae YS, Lee SY. Molecular ordering of ROS production, mitochondrial changes, and caspase activation during sodium salicylate-induced apoptosis. Free Radic Biol Med. 2003; 34(4):434-42. [PubMed: 12566069]

142. Storz P. Mitochondrial ROS--radical detoxification, mediated by protein kinase D. Trends Cell Biol. 2007; 17(1):13-8. [PubMed: 17126550]

143. Gottlieb E, Vander Heiden MG, Thompson CB. Bcl-x(L) prevents the initial decrease in mitochondrial membrane potential and subsequent reactive oxygen species production during tumor necrosis factor alpha-induced apoptosis. Mol Cell Biol. 2000; 20 (15):5680-9. [PubMed: 10891504]

144. Li PF, Dietz R, von Harsdorf R. p53 regulates mitochondrial membrane potential through reactive oxygen species and induces cytochrome c-independent apoptosis blocked by Bcl-2. Embo J. 1999; 18(21):6027-36. [PubMed: 10545114]

145. Lee $\mathrm{CH}$, et al. Novel 2-step synthetic indole compound 1,1,3-tri(3-indolyl)cyclohexane inhibits cancer cell growth in lung cancer cells and xenograft models. Cancer. 2008; 113(4):815-25. [PubMed: 18618576]

146. Qanungo S, et al. Epigallocatechin-3-gallate induces mitochondrial membrane depolarization and caspase-dependent apoptosis in pancreatic cancer cells. Carcinogenesis. 2005; 26(5):958-67. [PubMed: 15705601]

147. Shim HY, et al. Acacetin-induced apoptosis of human breast cancer MCF-7 cells involves caspase cascade, mitochondria-mediated death signaling and SAPK/JNK1/2-c-Jun activation. Mol Cells. 2007; 24(1):95-104. [PubMed: 17846503]

148. Zhang R, et al. In vitro and in vivo induction of apoptosis by capsaicin in pancreatic cancer cells is mediated through ROS generation and mitochondrial death pathway. Apoptosis. 2008; 13(12): 1465-78. [PubMed: 19002586]

149. Saitoh M, et al. Mammalian thioredoxin is a direct inhibitor of apoptosis signal-regulating kinase (ASK) 1. Embo J. 1998; 17(9):2596-606. [PubMed: 9564042]

150. Takeda K, et al. Roles of MAPKKK ASK1 in stress-induced cell death. Cell Struct Funct. 2003; 28(1):23-9. [PubMed: 12655147]

151. You H, Yamamoto K, Mak TW. Regulation of transactivation-independent proapoptotic activity of p53 by FOXO3a. Proc Natl Acad Sci U S A. 2006; 103(24):9051-6. [PubMed: 16757565]

152. Schulze-Osthoff K, et al. Depletion of the mitochondrial electron transport abrogates the cytotoxic and gene-inductive effects of TNF. Embo J. 1993; 12(8):3095-104. [PubMed: 8344250]

153. Xu YC, et al. Involvement of TRAF4 in oxidative activation of c-Jun N-terminal kinase. J Biol Chem. 2002; 277(31):28051-7. [PubMed: 12023963]

154. Wong GH, Goeddel DV. Induction of manganous superoxide dismutase by tumor necrosis factor: possible protective mechanism. Science. 1988; 242(4880):941-4. [PubMed: 3263703]

155. Chiu TT, et al. Protein kinase D2 mediates lysophosphatidic acid-induced interleukin 8 production in nontransformed human colonic epithelial cells through NF-kappaB. Am J Physiol Cell Physiol. 2007; 292(2):C767-77. [PubMed: 16928771]

156. Mihailovic T, et al. Protein kinase D2 mediates activation of nuclear factor kappaB by Bcr-Abl in Bcr-Abl+ human myeloid leukemia cells. Cancer Res. 2004; 64(24):8939-44. [PubMed: 15604256]

157. Song J, et al. PKD prevents H2O2-induced apoptosis via NF-kappaB and p38 MAPK in RIE-1 cells. Biochem B iophys Res Commun. 2009; 378(3):610-4.

158. Storz P, et al. Functional dichotomy of A20 in apoptotic and necrotic cell death. Biochem J. 2005; 387(Pt 1):47-55. [PubMed: 15527421]

159. Storz P, Doppler H, Toker A. Protein kinase D mediates mitochondrion-to-nucleus signaling and detoxification from mitochondrial reactive oxygen species. Mol Cell Biol. 2005; 25(19):852030. [PubMed: 16166634] 
160. Zhang W, et al. Protein kinase D specifically mediates apoptosis signal-regulating kinase 1-JNK signaling induced by H2O2 but not tumor necrosis factor. J Biol Chem. 2005; 280(19):19036-44. [PubMed: 15755722]

161. Kundu N, Zhang S, Fulton AM. Sublethal oxidative stress inhibits tumor cell adhesion and enhances experimental metastasis of murine mammary carcinoma. Clin Exp Metastasis. 1995; 13(1):16-22. [PubMed: 7820952]

162. Pelicano $\mathrm{H}$, et al. Mitochondrial dysfunction and reactive oxygen species imbalance promote breast cancer cell motility through a CXCL14-mediated mechanism. Cancer Res. 2009; 69(6): 2375-83. [PubMed: 19276362]

163. Hitchler MJ, Oberley LW, Domann FE. Epigenetic silencing of SOD2 by histone modifications in human breast cancer cells. Free Radic Biol Med. 2008; 45(11):1573-80. [PubMed: 18845242]

164. Hitchler MJ, et al. Epigenetic regulation of manganese superoxide dismutase expression in human breast cancer cells. Epigenetics. 2006; 1(4):163-71. [PubMed: 17965603]

165. Broom OJ, Massoumi R, Sjolander A. Alpha2beta1 integrin signalling enhances cyclooxygenase-2 expression in intestinal epithelial cells. J Cell Physiol. 2006; 209(3):950-8. [PubMed: 16972245]

166. Svineng G, et al. The role of reactive oxygen species in integrin and matrix metalloproteinase expression and function. Connect Tissue Res. 2008; 49(3):197-202. [PubMed: 18661342]

167. Taddei ML, et al. Integrin-mediated cell adhesion and spreading engage different sources of reactive oxygen species. Antioxid Redox Signal. 2007; 9(4):469-81. [PubMed: 17280488]

168. Ben Mahdi MH, Andrieu V, Pasquier C. Focal adhesion kinase regulation by oxidative stress in different cell types. IUBMB Life. 2000; 50(4-5):291-9. [PubMed: 11327323]

169. Chiarugi P. From anchorage dependent proliferation to survival: lessons from redox signalling. IUBMB Life. 2008; 60(5):301-7. [PubMed: 18421772]

170. Werner E, Werb Z. Integrins engage mitochondrial function for signal transduction by a mechanism dependent on Rho GTPases. J Cell Biol. 2002; 158(2):357-68. [PubMed: 12119354]

171. Giannoni E, et al. Redox regulation of anoikis resistance of metastatic prostate cancer cells: key role for Src and EGFR-mediated pro-survival signals. Oncogene. 2009; 28(20):2074-86. [PubMed: 19377510]

172. Radisky DC, et al. Rac1b and reactive oxygen species mediate MMP-3-induced EMT and genomic instability. Nature. 2005; 436(7047):123-7. [PubMed: 16001073]

173. Wu WS. The signaling mechanism of ROS in tumor progression. Cancer Metastasis Rev. 2006; 25(4):695-705. [PubMed: 17160708]

174. Tobar N, et al. RAC1 activity and intracellular ROS modulate the migratory potential of MCF-7 cells through a NADPH oxidase and NFkappaB-dependent mechanism. Cancer Lett. 2008; 267(1):125-32. [PubMed: 18433991]

175. Moldovan L, et al. The actin cytoskeleton reorganization induced by Rac1 requires the production of superoxide. Antioxid Redox Signal. 1999; 1(1):29-43. [PubMed: 11225730]

176. Eiseler T, et al. Protein kinase D1 regulates cofilin-mediated F-actin reorganization and cell motility through slingshot. Nat Cell Biol. 2009; 11(5):545-56. [PubMed: 19329994]

177. Kim JS, Huang TY, Bokoch GM. Reactive oxygen species regulate a slingshot-cofilin activation pathway. Mol Biol Cell. 2009; 20(11):2650-60. [PubMed: 19339277]

178. Sundaresan M, et al. Regulation of reactive-oxygen-species generation in fibroblasts by Rac1. Biochem J. 1996; 318 (Pt 2):379-82. [PubMed: 8809022]

179. Gianni D, et al. The involvement of the tyrosine kinase c-Src in the regulation of reactive oxygen species generation mediated by NADPH oxidase-1. Mol Biol Cell. 2008; 19 (7):2984-94. [PubMed: 18463161]

180. Diaz B, et al. Tks5-dependent, nox-mediated generation of reactive oxygen species is necessary for invadopodia formation. Sci Signal. 2009; 2(88):ra53. [PubMed: 19755709]

181. Brown NS, Bicknell R. Hypoxia and oxidative stress in breast cancer. Oxidative stress: its effects on the growth, metastatic potential and response to therapy of breast cancer. Breast Cancer Res. 2001; 3(5):323-7. [PubMed: 11597322] 
182. Duffy MJ, et al. Metalloproteinases: role in breast carcinogenesis, invasion and metastasis. Breast Cancer R es. 2000; 2(4):252-7.

183. Nelson AR, et al. Matrix metalloproteinases: biologic activity and clinical implications. J Clin Oncol. 2000; 18(5):1135-49. [PubMed: 10694567]

184. Nelson KK, Melendez JA. Mitochondrial redox control of matrix metalloproteinases. Free Radic Biol Med. 2004; 37(6):768-84. [PubMed: 15304253]

185. Brenneisen P, Sies H, Scharffetter-Kochanek K. Ultraviolet-B irradiation and matrix metalloproteinases: from induction via signaling to initial events. Ann N Y Acad Sci. 2002; 973:31-43. [PubMed: 12485830]

186. Kheradmand F, et al. Role of Rac1 and oxygen radicals in collagenase-1 expression induced by cell shape change. Science. 1998; 280(5365):898-902. [PubMed: 9572733]

187. Wenk J, et al. Stable overexpression of manganese superoxide dismutase in mitochondria identifies hydrogen peroxide as a major oxidant in the AP-1-mediated induction of matrixdegrading metalloprotease-1. J Biol Chem. 1999; 274(36):25869-76. [PubMed: 10464329]

188. Westermarck J, Kahari VM. Regulation of matrix metalloproteinase expression in tumor invasion. Faseb J. 1999; 13(8):781-92. [PubMed: 10224222]

189. Rajagopalan $\mathrm{S}$, et al. Reactive oxygen species produced by macrophage-derived foam cells regulate the activity of vascular matrix metalloproteinases in vitro. Implications for atherosclerotic plaque stability. J Clin Invest. 1996; 98(11):2572-9. [PubMed: 8958220]

190. van Wetering S, et al. Reactive oxygen species mediate Rac-induced loss of cell-cell adhesion in primary human endothelial cells. J Cell Sci. 2002; 115(Pt 9):1837-46. [PubMed: 11956315]

191. Cheng GC, et al. Oxidative stress and thioredoxin-interacting protein promote intravasation of melanoma cells. Exp Cell Res. 2004; 300(2):297-307. [PubMed: 15474995]

192. Roebuck KA. Oxidant stress regulation of IL-8 and ICAM-1 gene expression: differential activation and binding of the transcription factors AP-1 and NF-kappaB (Review). Int J Mol Med. 1999; 4(3):223-30. [PubMed: 10425270]

193. Huot J, et al. Oxidative stress-induced actin reorganization mediated by the $\mathrm{p} 38$ mitogen-activated protein kinase/heat shock protein 27 pathway in vascular endothelial cells. Circ Res. 1997; 80(3): 383-92. [PubMed: 9048659]

194. Dewhirst MW, Cao Y, Moeller B. Cycling hypoxia and free radicals regulate angiogenesis and radiotherapy response. Nat Rev Cancer. 2008; 8(6):425-37. [PubMed: 18500244]

195. Hockel M, Vaupel P. Tumor hypoxia: definitions and current clinical, biologic, and molecular aspects. J Natl Cancer Inst. 2001; 93(4):266-76. [PubMed: 11181773]

196. Pani G, et al. Redox-based escape mechanism from death: the cancer lesson. Antioxid Redox Signal. 2009; 11(11):2791-806. [PubMed: 19686053]

197. Dang CV, Semenza GL. Oncogenic alterations of metabolism. Trends Biochem Sci. 1999; 24(2): 68-72. [PubMed: 10098401]

198. Ganapathy V, Thangaraju M, Prasad PD. Nutrient transporters in cancer: relevance to Warburg hypothesis and beyond. Pharmacol Ther. 2009; 121(1):29-40. [PubMed: 18992769]

199. Hsu PP, Sabatini DM. Cancer cell metabolism: Warburg and beyond. Cell. 2008; 134(5):703-7. [PubMed: 18775299]

200. Harris AL. Hypoxia--a key regulatory factor in tumour growth. Nat Rev Cancer. 2002; 2(1):3847. [PubMed: 11902584]

201. Kaelin WG Jr, Ratcliffe PJ. Oxygen sensing by metazoans: the central role of the HIF hydroxylase pathway. Mol Cell. 2008; 30(4):393-402. [PubMed: 18498744]

202. Pouyssegur J, Dayan F, Mazure NM. Hypoxia signalling in cancer and approaches to enforce tumour regression. Nature. 2006; 441(7092):437-43. [PubMed: 16724055]

203. Erler JT, et al. Lysyl oxidase is essential for hypoxia-induced metastasis. Nature. 2006; 440(7088):1222-6. [PubMed: 16642001]

204. Rofstad EK, et al. Acidic extracellular $\mathrm{pH}$ promotes experimental metastasis of human melanoma cells in athymic nude mice. Cancer Res. 2006; 66(13):6699-707. [PubMed: 16818644] 
205. Claffey KP, et al. Expression of vascular permeability factor/vascular endothelial growth factor by melanoma cells increases tumor growth, angiogenesis, and experimental metastasis. Cancer Res. 1996; 56(1):172-81. [PubMed: 8548760]

206. Senger DR, et al. Vascular permeability factor, tumor angiogenesis and stroma generation. Invasion Metastasis. 1994; 14(1-6):385-94. [PubMed: 7544775]

207. Rabbani ZN, et al. Antiangiogenic action of redox-modulating Mn(III) ortho-tetrakis-Nethylpyridylporphyrin, MnTE-2-PyP(5+), via suppression of oxidative stress in a mouse model of breast tumor. Free Radic Biol Med. 2009

208. Brown LF, et al. Vascular permeability factor/vascular endothelial growth factor: a multifunctional angiogenic cytokine. Exs. 1997; 79:233-69. [PubMed: 9002222]

209. Murakami M, Simons M. Fibroblast growth factor regulation of neovascularization. Curr Opin Hematol. 2008; 15(3):215-20. [PubMed: 18391788]

210. Wouters BG, Koritzinsky M. Hypoxia signalling through mTOR and the unfolded protein response in cancer. Nat Rev Cancer. 2008; 8(11):851-64. [PubMed: 18846101]

211. Spitz DR, et al. Glucose deprivation-induced oxidative stress in human tumor cells. A fundamental defect in metabolism? Ann N Y Acad Sci. 2000; 899:349-62. [PubMed: 10863552]

212. Bertout JA, Patel SA, Simon MC. The impact of O2 availability on human cancer. Nat Rev Cancer. 2008; 8(12):967-75. [PubMed: 18987634]

213. Gardner LB, Corn PG. Hypoxic regulation of mRNA expression. Cell Cycle. 2008; 7(13):191624. [PubMed: 18604161]

214. Xia C, et al. Reactive oxygen species regulate angiogenesis and tumor growth through vascular endothelial growth factor. Cancer Res. 2007; 67(22):10823-30. [PubMed: 18006827]

215. Govindarajan B, et al. Overexpression of Akt converts radial growth melanoma to vertical growth melanoma. J Clin Invest. 2007; 117(3):719-29. [PubMed: 17318262]

216. Ma J, et al. PTEN regulate angiogenesis through PI3K/Akt/VEGF signaling pathway in human pancreatic cancer cells. Mol Cell Biochem. 2009

217. Wartenberg M, et al. Inhibition of tumor-induced angiogenesis and matrix-metalloproteinase expression in confrontation cultures of embryoid bodies and tumor spheroids by plant ingredients used in traditional chinese medicine. Lab Invest. 2003; 83 (1):87-98. [PubMed: 12533689]

218. Milligan SA, Owens MW, Grisham MB. Augmentation of cytokine-induced nitric oxide synthesis by hydrogen peroxide. Am J Physiol. 1996; 271(1 Pt 1):L114-20. [PubMed: 8760140]

219. Bao S, et al. Glioma stem cells promote radioresistance by preferential activation of the DNA damage response. Nature. 2006; 444(7120):756-60. [PubMed: 17051156]

220. Visvader JE, Lindeman GJ. Cancer stem cells in solid tumours: accumulating evidence and unresolved questions. Nat Rev Cancer. 2008; 8(10):755-68. [PubMed: 18784658]

221. Trachootham D, Alexandre J, Huang P. Targeting cancer cells by ROS-mediated mechanisms: a radical therapeutic approach? Nat Rev Drug Discov. 2009; 8(7):579-91. [PubMed: 19478820]

222. Diehn M, et al. Association of reactive oxygen species levels and radioresistance in cancer stem cells. Nature. 2009; 458(7239):780-3. [PubMed: 19194462]

223. Tothova Z, et al. FoxOs are critical mediators of hematopoietic stem cell resistance to physiologic oxidative stress. Cell. 2007; 128(2):325-39. [PubMed: 17254970]

224. Shackleton M, et al. Generation of a functional mammary gland from a single stem cell. Nature. 2006; 439(7072):84-8. [PubMed: 16397499]

225. Ward JF. Biochemistry of DNA lesions. Radiat Res Suppl. 1985; 8:S103-11. [PubMed: 3867077]

226. Imlay JA, Chin SM, Linn S. Toxic DNA damage by hydrogen peroxide through the Fenton reaction in vivo and in vitro. Science. 1988; 240(4852):640-2. [PubMed: 2834821]

227. Maynard S, et al. Base excision repair of oxidative DNA damage and association with cancer and aging. Carcinogenesis. 2009; 30(1):2-10. [PubMed: 18978338]

228. Wiseman H, Halliwell B. Damage to DNA by reactive oxygen and nitrogen species: role in inflammatory disease and progression to cancer. Biochem J. 1996; 313 (Pt 1):17-29. [PubMed: 8546679]

229. Mitra S, et al. Complexities of the DNA base excision repair pathway for repair of oxidative DNA damage. Environ Mol Mutagen. 2001; 38(2-3):180-90. [PubMed: 11746753] 
230. Levine RL. Carbonyl modified proteins in cellular regulation, aging, and disease. Free Radic Biol Med. 2002; 32(9):790-6. [PubMed: 11978480]

231. Squier TC, Bigelow DJ. Protein oxidation and age-dependent alterations in calcium homeostasis. Front Biosci. 2000; 5:D504-26. [PubMed: 10799358]

232. Wells-Knecht MC, et al. Age-dependent increase in ortho-tyrosine and methionine sulfoxide in human skin collagen is not accelerated in diabetes. Evidence against a generalized increase in oxidative stress in diabetes. J Clin Invest. 1997; 100(4):839-46. [PubMed: 9259583]

233. Meng TC, Fukada T, Tonks NK. Reversible oxidation and inactivation of protein tyrosine phosphatases in vivo. Mol Cell. 2002; 9(2):387-99. [PubMed: 11864611]

234. Burhans WC, Weinberger M. DNA replication stress, genome instability and aging. Nucleic Acids Res. 2007; 35(22):7545-56. [PubMed: 18055498]

235. Epe B. Role of endogenous oxidative DNA damage in carcinogenesis: what can we learn from repair-deficient mice? Biol Chem. 2002; 383(3-4):467-75. [PubMed: 12033436]

236. Franco R, et al. Oxidative stress, DNA methylation and carcinogenesis. Cancer Lett. 2008; 266(1):6-11. [PubMed: 18372104]

237. Gardner HW. Oxygen radical chemistry of polyunsaturated fatty acids. Free Radic Biol Med. 1989; 7(1):65-86. [PubMed: 2666279]

238. North JA, Spector AA, Buettner GR. Cell fatty acid composition affects free radical formation during lipid peroxidation. Am J Physiol. 1994; 267(1 Pt 1):C177-88. [PubMed: 8048478]

239. Burcham PC. Genotoxic lipid peroxidation products: their DNA damaging properties and role in formation of endogenous DNA adducts. Mutagenesis. 1998; 13(3):287-305. [PubMed: 9643589]

240. Catala A. Lipid peroxidation of membrane phospholipids generates hydroxy-alkenals and oxidized phospholipids active in physiological and/or pathological conditions. Chem Phys Lipids. 2009; 157(1):1-11. [PubMed: 18977338]

241. Lauschke $\mathrm{H}$, et al. Lipid peroxidation as additional marker in patients with colorectal cancer. Results of a preliminary study. Eur Surg Res. 2002; 34(5):346-50. [PubMed: 12364818]

242. Alexandre $\mathbf{J}$, et al. Accumulation of hydrogen peroxide is an early and crucial step for paclitaxelinduced cancer cell death both in vitro and in vivo. Int J Cancer. 2006; 119(1):41-8. [PubMed: 16450384]

243. Bairati I, et al. Randomized trial of antioxidant vitamins to prevent acute adverse effects of radiation therapy in head and neck cancer patients. J Clin Oncol. 2005; 23(24):5805-13. [PubMed: 16027437]

244. Llobet D, et al. Antioxidants block proteasome inhibitor function in endometrial carcinoma cells. Anticancer Drugs. 2008; 19(2):115-24. [PubMed: 18176107]

245. Gahr S, et al. The combination of the histone-deacetylase inhibitor trichostatin A and gemcitabine induces inhibition of proliferation and increased apoptosis in pancreatic carcinoma cells. Int $\mathrm{J}$ Oncol. 2007; 31(3):567-76. [PubMed: 17671683]

246. Lee KH, et al. Epigenetic silencing of MicroRNA miR-107 regulates cyclin-dependent kinase 6 expression in pancreatic cancer. Pancreatology. 2009; 9(3):293-301. [PubMed: 19407485]

247. Shankar S, et al. EGCG inhibits growth, invasion, angiogenesis and metastasis of pancreatic cancer. Front Biosci. 2008; 13:440-52. [PubMed: 17981559]

248. Shankar S, Suthakar G, Srivastava RK. Epigallocatechin-3-gallate inhibits cell cycle and induces apoptosis in pancreatic cancer. Front Biosci. 2007; 12:5039-51. [PubMed: 17569628]

249. Srivastava SK, Singh SV. Cell cycle arrest, apoptosis induction and inhibition of nuclear factor kappa B activation in anti-proliferative activity of benzyl isothiocyanate against human pancreatic cancer cells. Carcinogenesis. 2004; 25(9):1701-9. [PubMed: 15117814]

250. Donadelli M, et al. Synergistic inhibition of pancreatic adenocarcinoma cell growth by trichostatin A and gemcitabine. Biochim Biophys Acta. 2007; 1773(7):1095-106. [PubMed: 17555830]

251. Sahu RP, et al. Benzyl isothiocyanate mediated generation of reactive oxygen species causes cell cycle arrest and induces apoptosis via activation of MAPK in human pancreatic cancer cells. Carcinogenesis. 2009 
252. Marchetti M, et al. Sulindac enhances the killing of cancer cells exposed to oxidative stress. PLoS One. 2009; 4(6):e5804. [PubMed: 19503837]

253. Loaiza-Perez AI, et al. Aryl hydrocarbon receptor activation of an antitumor aminoflavone: basis of selective toxicity for MCF-7 breast tumor cells. Mol Cancer Ther. 2004; 3(6):715-25. [PubMed: 15210858]

254. McLean L, et al. Aminoflavone induces oxidative DNA damage and reactive oxidative speciesmediated apoptosis in breast cancer cells. Int J Cancer. 2008; 122(7):1665-74. [PubMed: 18059023]

255. Chen $\mathrm{CY}$, et al. Isokotomolide A, a new butanolide extracted from the leaves of Cinnamomum kotoense, arrests cell cycle progression and induces apoptosis through the induction of p53/p21 and the initiation of mitochondrial system in human non-small cell lung cancer A549 cells. Eur J Pharmacol. 2007; 574(2-3):94-102. [PubMed: 17707793]

256. Kuo PL, Chen CY, Hsu YL. Isoobtusilactone A induces cell cycle arrest and apoptosis through reactive oxygen species/apoptosis signal-regulating kinase 1 signaling pathway in human breast cancer cells. Cancer Res. 2007; 67(15):7406-20. [PubMed: 17671211]

257. McLachlan A, et al. Pancratistatin: a natural anti-cancer compound that targets mitochondria specifically in cancer cells to induce apoptosis. Apoptosis. 2005; 10(3):619-30. [PubMed: 15909123]

258. Sandhya T, et al. Potential of traditional ayurvedic formulation, Triphala, as a novel anticancer drug. Cancer Lett. 2006; 231(2):206-14. [PubMed: 15899544]

259. Sandhya T, Mishra KP. Cytotoxic response of breast cancer cell lines, MCF 7 and T 47 D to triphala and its modification by antioxidants. Cancer Lett. 2006; 238(2):304-13. [PubMed: 16135398]

260. Siedlakowski P, et al. Synergy of Pancratistatin and Tamoxifen on breast cancer cells in inducing apoptosis by targeting mitochondria. Cancer Biol Ther. 2008; 7(3):376-84. [PubMed: 18075307]

261. Dayal D, et al. Mitochondrial complex II dysfunction can contribute significantly to genomic instability after exposure to ionizing radiation. Radiat Res. 2009; 172(6):737-45. [PubMed: 19929420]

262. Carew JS, et al. Mitochondrial DNA mutations in primary leukemia cells after chemotherapy: clinical significance and therapeutic implications. Leukemia. 2003; 17(8):1437-47. [PubMed: 12886229]

263. Vaughn AE, Deshmukh M. Glucose metabolism inhibits apoptosis in neurons and cancer cells by redox inactivation of cytochrome c. Nat Cell Biol. 2008; 10(12):1477-83. [PubMed: 19029908]

264. Aykin-Burns N, et al. Increased levels of superoxide and $\mathrm{H} 2 \mathrm{O} 2$ mediate the differential susceptibility of cancer cells versus normal cells to glucose deprivation. Biochem J. 2009; 418(1):29-37. [PubMed: 18937644]

265. Ahmad IM, et al. 2-Deoxyglucose combined with wild-type p53 overexpression enhances cytotoxicity in human prostate cancer cells via oxidative stress. Free Radic Biol Med. 2008; 44(5):826-34. [PubMed: 18155176]

266. Coleman MC, et al. 2-deoxy-D-glucose causes cytotoxicity, oxidative stress, and radiosensitization in pancreatic cancer. Free Radic Biol Med. 2008; 44(3):322-31. [PubMed: 18215740]

267. Fath MA, et al. Mitochondrial electron transport chain blockers enhance 2-deoxy-D-glucose induced oxidative stress and cell killing in human colon carcinoma cells. Cancer Biol Ther. 2009; 8(13):1228-36. [PubMed: 19411865]

268. Algul H, et al. Mechanisms of disease: chronic inflammation and cancer in the pancreas--a potential role for pancreatic stellate cells? Nat Clin Pract Gastroenterol Hepatol. 2007; 4(8):45462. [PubMed: 17667994]

269. Greer JB, Whitcomb DC. Inflammation and pancreatic cancer: an evidence-based review. Curr Opin Pharmacol. 2009

270. Lowenfels AB, et al. Pancreatitis and the risk of pancreatic cancer. International Pancreatitis Study Group. N Engl J Med. 1993; 328(20):1433-7. [PubMed: 8479461] 
271. Antosiewicz J, et al. c-Jun NH(2)-terminal kinase signaling axis regulates diallyl trisulfideinduced generation of reactive oxygen species and cell cycle arrest in human prostate cancer cells. Cancer Res. 2006; 66(10):5379-86. [PubMed: 16707465]

272. Townsend DM, Tew KD. Pharmacology of a mimetic of glutathione disulfide, NOV-002. Biomed Pharmacother. 2009; 63(2):75-8. [PubMed: 18851905]

273. Storz $\mathrm{P}$, et al. FOXO3a promotes tumor cell invasion through the induction of matrix metalloproteinases. Mol Cell Biol. 2009; 29(18):4906-17. [PubMed: 19564415] 


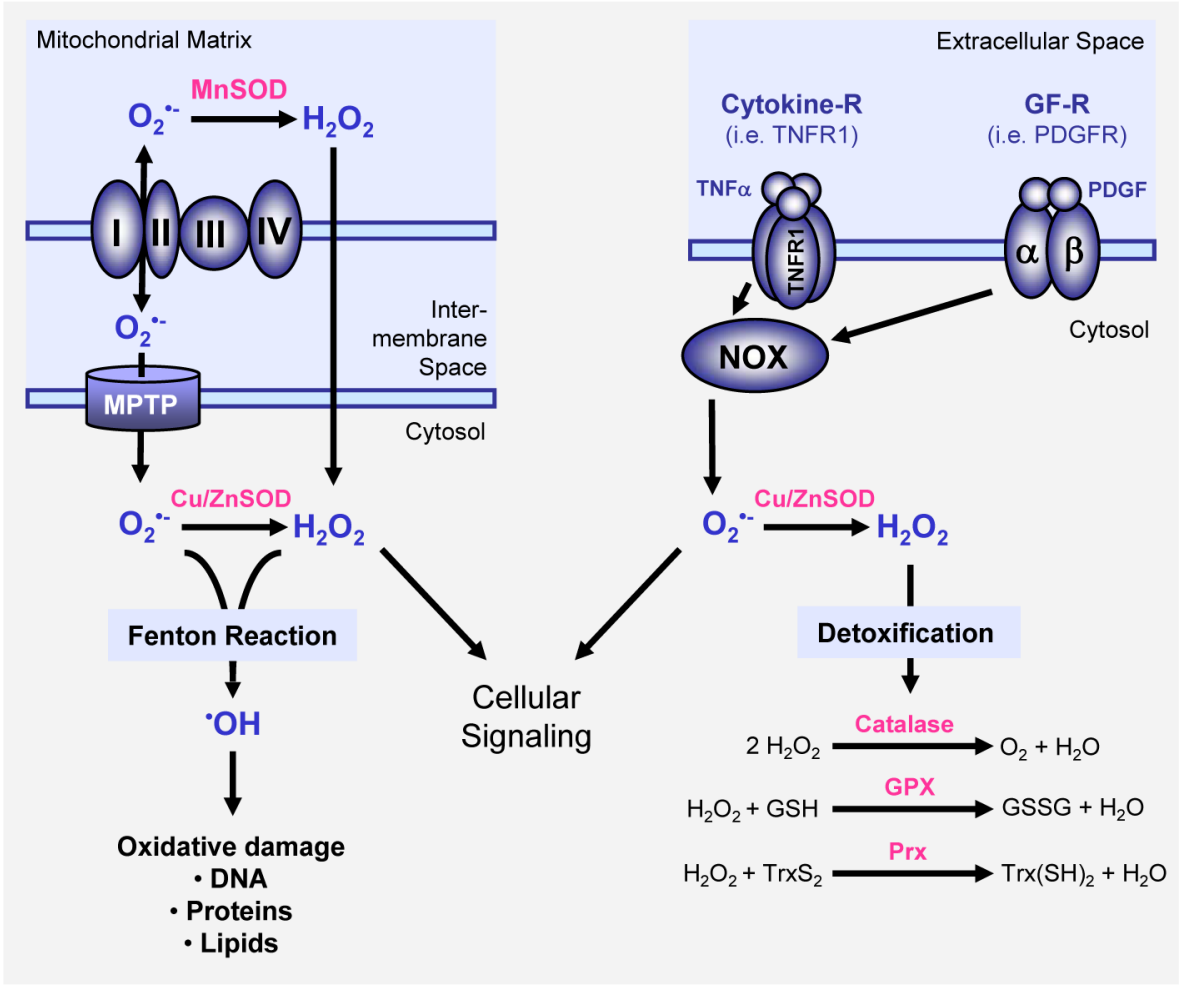

Figure 1. Major mechanisms of ROS generation and detoxification

Superoxide $\left(\mathrm{O}^{*-}\right)$ radicals are generated at the inner membrane of the mitochondria as a byproduct of the electron transport chain and then release into the mitochondrial matrix or the cytosol via the mitochondrial permeability transition pore (MPTP). Superoxide is also generated through activation of NADPH oxidases (NOX) for example in response to growth factor receptor (GF-R) or cytokine receptor activation. SOD enzymes, such as MnSOD in the mitochondrial matrix or $\mathrm{Cu} / \mathrm{ZnSOD}$ in the cytosol reduce superoxide to $\mathrm{H}_{2} \mathrm{O}_{2}$. Several cytosolic antioxidant systems, including catalase, glutathione peroxidase (GPX) and peroxiredoxins (Prx) detoxify cells from hydrogen peroxide by reducing it to water. Both hydrogen peroxide and superoxide contribute to cellular signaling but also can form hydroxyl radicals ( $\left.{ }^{\circ} \mathrm{OH}\right)$. Hydroxyl radicals are generated from $\mathrm{O}^{\circ-}$ and $\mathrm{H}_{2} \mathrm{O}_{2}$ in the Fenton reaction and have damaging functions for proteins, DNA and lipids. 


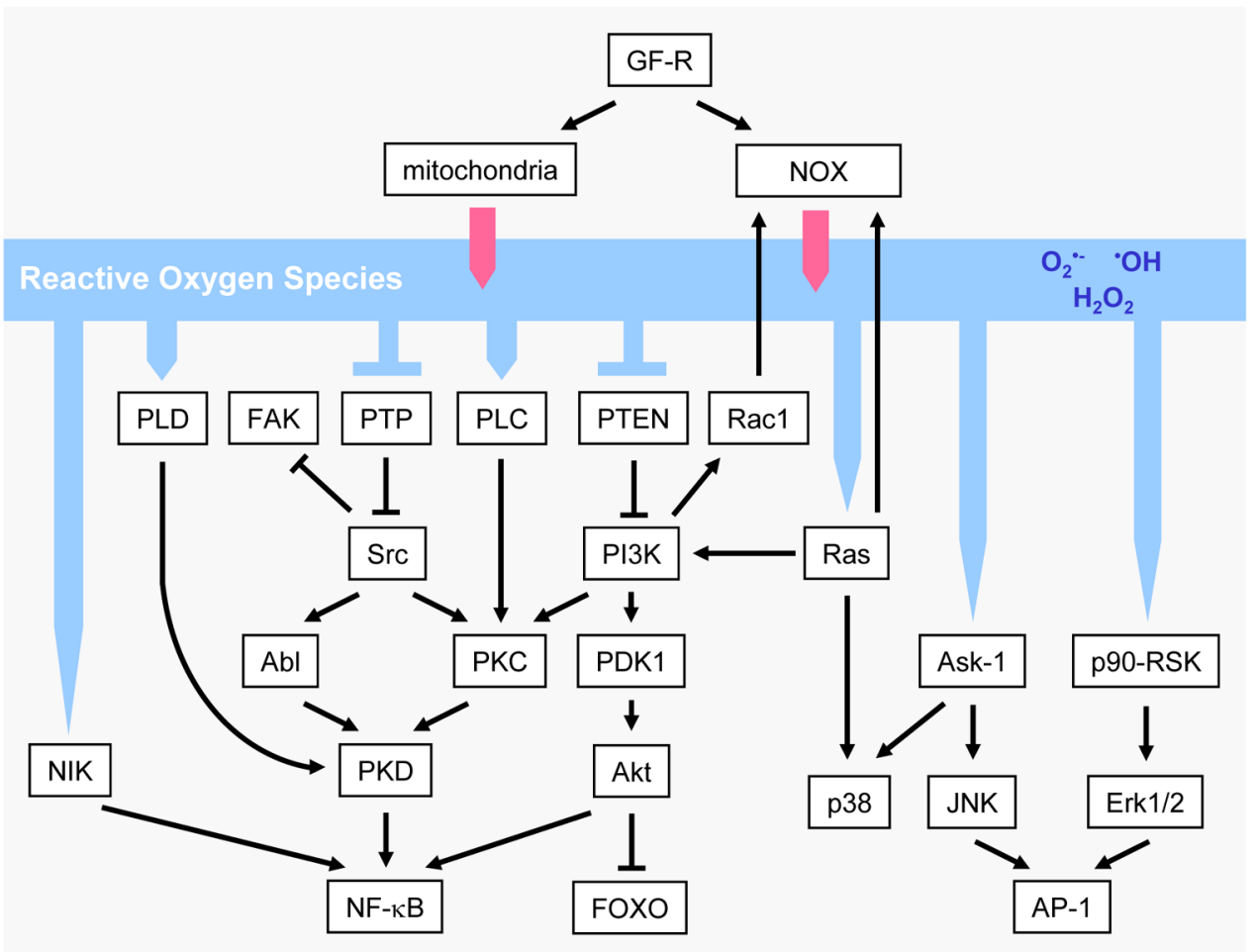

Figure 2. ROS-induced cellular signaling

Reactive oxygen species in cells can be generated by growth factor signaling through activation of the NADPH oxidase NOX1 or through the mitochondria. These ROS then can induce cellular signaling cascades by reversible oxidation of phosphatases such as PTEN or PTP in their active site cysteins or by direct oxidation of kinases such as Src. This leads to the activation of several signaling cascades such as a Src/PKD1-dependent NF- $\kappa \mathrm{B}$ activation mechanism, the MAPK (Erk1/2, p38 and JNK) signaling cascades, as well as the PI3K/Akt signaling pathway. Other mechanisms, by which ROS induce cellular signaling is through activation of redox-regulated transcription factors such as AP-1 or FOXO. 


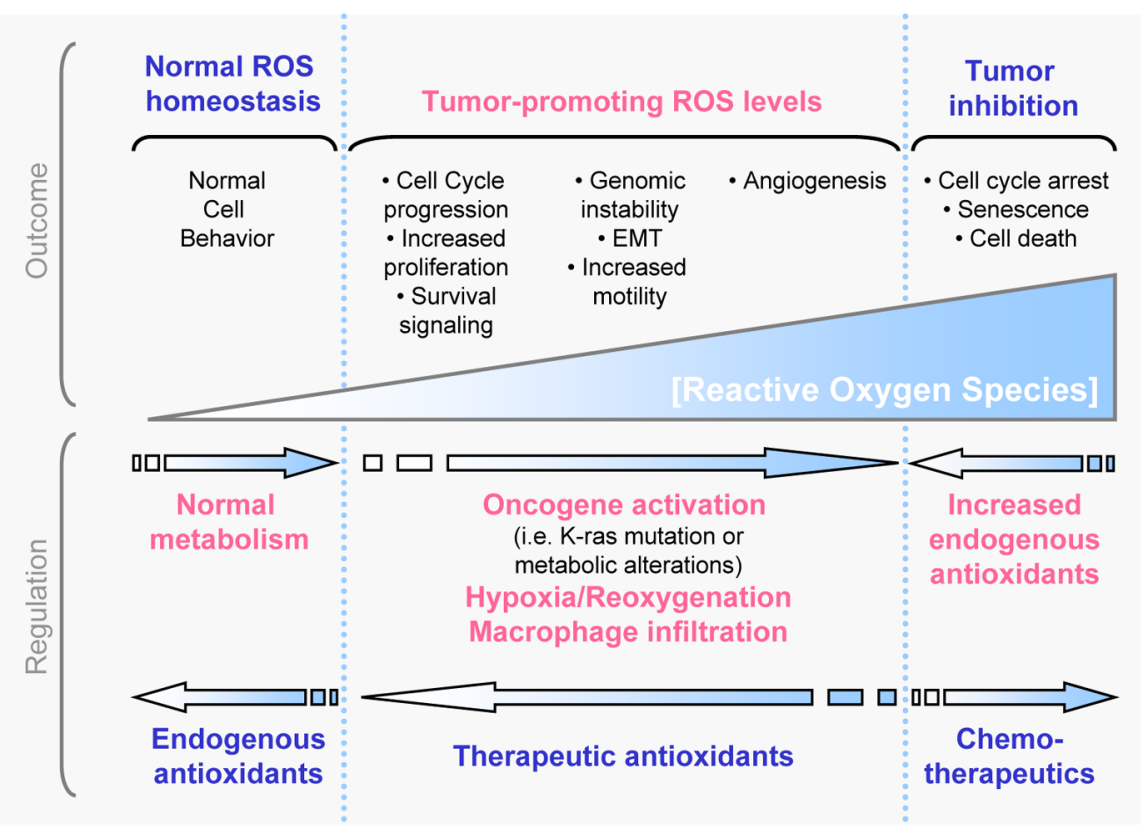

Figure 3. Generation, regulation and effects of cellular ROS

ROS are generated in normal cellular processes and cells express antioxidants to deplete intracellular levels of oxygen radicals. Tumorigenic events including oncogene activation (i.e. mutation of K-ras), metabolic alterations or macrophage infiltration or hypoxia/ reoxygenation processes in tissues can increase intracellular ROS levels and promote tumor formation or progression. These tumor-promoting ROS levels can lead to cell cycle progression, increased proliferation and survival signaling, EMT, increased motility, genomic instability and increased angiogenesis and may be negatively-regulated by therapeutic antioxidants. Finally, excessive increase in intracellular ROS levels as mediated by chemotherapeutics, can induce cell cycle arrest, senescence or cell death of tumor cells, but may be repulsed by the tumor cells through an increase in the expression of endogenous antioxidants. 